\title{
Competing or Complementary Strategies? Protecting Indigenous Rights and Paying to Conserve Forests
}

\section{William Savedoff}

\author{
Abstract
}

In 2007, the UN General Assembly adopted the Declaration on the Rights of Indigenous Peoples and the United Nations Framework Convention on Climate Change (UNFCCC) endorsed the Bali Action Plan to pay for reductions in tropical deforestation. While many saw these initiatives as complementary, others considered the Bali Action Plan a threat to indigenous peoples' rights.

This paper reviews the history of efforts to protect indigenous rights and to pay for conserving forests and analyzes how they might be competing or complementary strategies. It then presents country experiences that show indigenous peoples have achieved tangible political benefits in many countries and internationally by using their leverage over and participation in Reducing Emissions from Deforestation and Degradation Plus (REDD+) negotiations. Nevertheless, these experiences also show that insisting on preconditions for REDD+ national performance payments may have inadvertently harmed indigenous peoples by contributing to delays in implementation.

Today, the movements for indigenous rights and for slowing deforestation are inextricably entwined. Whereas critics fear implementation of REDD+ will harm indigenous peoples, it is the failure of REDD+ programs to influence national action to slow deforestation which represents the greater risk. In this way, the two movements face a common challenge to refocus attention on the national policies and actions that must change to protect both indigenous rights and tropical forests.

Keywords: REDD+, deforestation, climate change, economic development, indigenous peoples, human rights, public policy, political economy

JEL: O19, Q01, Q23, Q28, P48
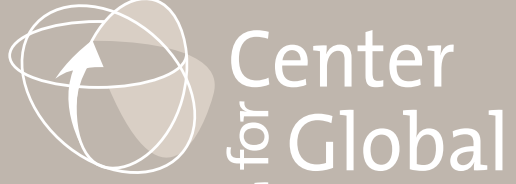

Working Pa Paper 490 


\title{
Competing or Complementary Strategies? Protecting Indigenous Rights and Paying to Conserve Forests
}

\author{
William Savedoff \\ Center for Global Development
}

This paper benefited substantially from comments received from Frances Seymour. I also appreciate the support and encouragement I received from Frances Seymour, Jonah Busch, and Michele de Nevers in this and earlier research collaborations. I am indebted to Liliana Lozano, Tim Laing, Chip Fay and Ho-Ming So Denduangrudee for their detailed case studies of Peru, Guyana and Indonesia. I would furthermore like to thank Emily Foecke-Munden who provided extensive research support, including a detailed systematic review of the literature, and Mallika Snyder who provided additional research assistance as the paper reached its conclusion. Any errors or omissions which remain in the paper are my sole responsibility.

The Center for Global Development is grateful for contributions from the Norwegian Agency for Development Cooperation in support of this work.

This paper is part of the CGD Climate and Forest Paper Series. The full series is available at https://www.cgdev.org/page/wfwn-paper-series

William Savedoff, 2018. "Competing or Complementary Strategies? Protecting Indigenous Rights and Paying to Conserve Forests." CGD Working Paper 490. Washington, DC: Center for Global Development. https://www.cgdev.org/publication/competing-orcomplementary-strategies-protecting-indigenous-rights-and-paying-conserve

Center for Global Development 2055 L Street NW Washington, DC 20036

202.416.4000

(f) 202.416 .4050

www.cgdev.org
The Center for Global Development works to reduce global poverty and improve lives through innovative economic research that drives better policy and practice by the world's top decision makers. Use and dissemination of this Working Paper is encouraged; however, reproduced copies may not be used for commercial purposes. Further usage is permitted under the terms of the Creative Commons License.

The views expressed in CGD Working Papers are those of the authors and should not be attributed to the board of directors, funders of the Center for Global Development, or the authors' respective organizations. 


\section{Contents}

1. Introduction: Two movements, two strategies? .............................................................. 1

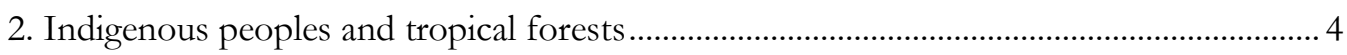

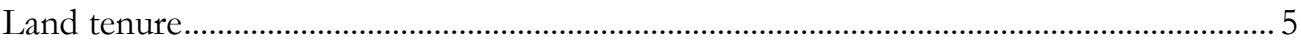

Health and social well-being of indigenous peoples ......................................................... 7

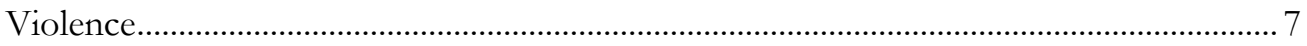

The struggle for rights and recognition............................................................................. 7

3. REDD+ and tropical forests ........................................................................................ 10

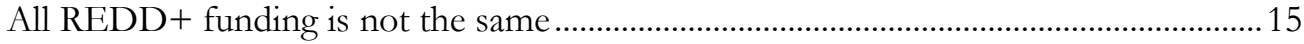

4. Competing or complementary strategies? Risk and opportunities of REDD+

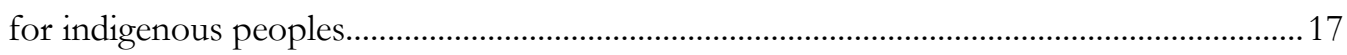

5. Which risks and opportunities have materialized?............................................................ 19

Payments to communities, firms, and landowners...............................................................19

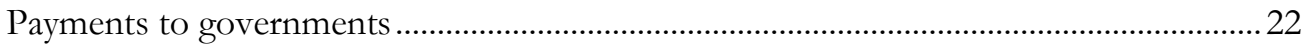

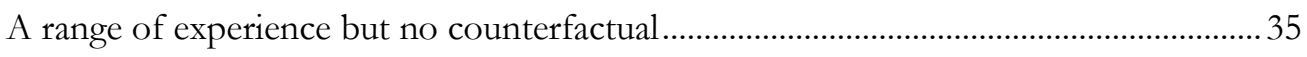

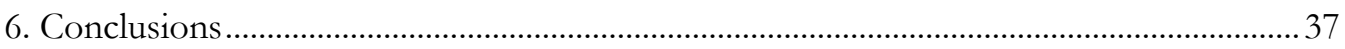

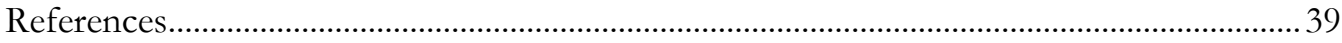

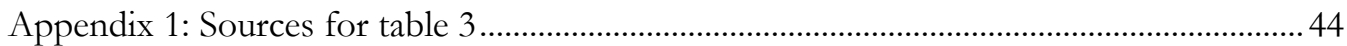

Appendix 2: A formal model to investigate compatibility of forest protection and

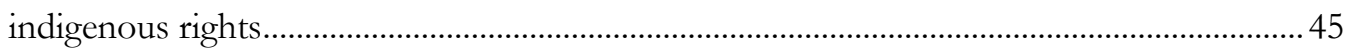

Appendix 3: Search process for prospective criticism of REDD $+\ldots \ldots \ldots \ldots \ldots \ldots \ldots \ldots \ldots \ldots \ldots \ldots \ldots . . . .47$

Appendix 4: 43 articles with prospective analysis of the impact of REDD+ on

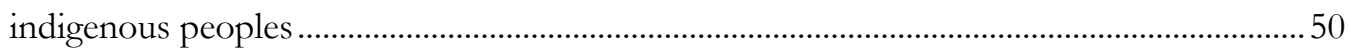




\section{Introduction: Two movements, two strategies?}

In 2007, when 180 countries endorsed the Bali Action Plan to protect tropical forests, many advocates for indigenous peoples living in these forests were supportive, but others were not. The reasons for opposition were understandable in light of longstanding repression of indigenous peoples and especially concerns that creating tradeable carbon credits for forested land would lead to more land grabs and evictions. Since that time, international negotiators and agencies have tried to address indigenous peoples' concerns through a mix of amendments to the original agreement, new accords, and procedures. Also, the expected carbon markets never materialized, so that most funding for Reducing Emissions from Deforestation and Degradation Plus (REDD+) comes from public coffers rather than private trades.

Ten years have passed and indigenous peoples still face repression and insecure land tenure, but the major drivers of deforestation remain corruption and the expansion of agriculture, mining and human settlement rather than forest conservation efforts. Still, opposition to REDD + may have benefitted indigenous peoples in unexpected ways; in particular, many indigenous groups have used REDD+ negotiations to improve their status through representation on national committees, demanding demarcation and protection of lands, and in some cases, obtaining financial benefits for their stewardship of the forests.

The story of REDD+ and indigenous peoples therefore is the confluence of two large trends (see table 1). The first is the indigenous peoples' movement, with its long history of struggling for autonomy, rights, and lands. This movement reached international milestones in the ILO Convention 169 and later in UNDRIP. The second trend is the negotiation of REDD+ to protect forests as part of averting climate change, which was neglected in the Kyoto Protocol but eventually gained international support in the UNFCCC conference in Bali and formalization in the subsequent Warsaw Agreement. Both trends have been influenced by a third development: the shift in REDD+ from private market transaction proposal to public aid funding and from projects to policies. REDD+ underwent "aidification" with the introduction of preconditions for receiving performance payments and subjecting disbursements to the rules and procedures applied by public development agencies to conventional programs. 
Table 1. Milestones in the development of REDD+ and Indigenous Rights Movements

\begin{tabular}{|c|c|c|}
\hline REDD+ Milestones & Year & Indigenous Rights Milestones \\
\hline \multirow[t]{2}{*}{$\begin{array}{c}\text { FAO, World Bank, UNDP, and WRI launch The } \\
\text { Tropical Forest Action Plan }\end{array}$} & 1985 & \\
\hline & 1989 & ILO indigenous and Tribal Peoples Convention 169 \\
\hline Deforestation in the Amazon reaches all-time high & 1995 & \\
\hline \multirow[t]{3}{*}{ UNFCCC agrees to the Kyoto Protocol } & 1997 & $\begin{array}{c}\text { UNCERD issues recommendation requiring states } \\
\text { to obtain the free, prior, and informed consent of } \\
\text { indigenous peoples }\end{array}$ \\
\hline & 2000 & $\begin{array}{l}\text { UN Permanent Forum on Indigenous Issues } \\
\text { established }\end{array}$ \\
\hline & 2001 & $\begin{array}{c}\text { UN Commission on Human Rights appoints a } \\
\text { Special Rapporteur on the rights of indigenous } \\
\text { peoples }\end{array}$ \\
\hline $\begin{array}{c}\text { Coalition for Rainforest Nations requests UNFCCC } \\
\text { agenda item on RED in developing countries }\end{array}$ & 2005 & \\
\hline \multirow[t]{2}{*}{ In Bali, UNFCCC agrees to develop REDD } & 2007 & $\begin{array}{l}\text { UN General Assembly adopts Declaration on the } \\
\text { Rights of Indigenous Peoples }\end{array}$ \\
\hline & 2008 & $\begin{array}{c}\text { International Indigenous Peoples' Forum on } \\
\text { Climate Change established }\end{array}$ \\
\hline $\begin{array}{l}\text { REDD expanded to REDD+, importance of } \\
\text { engagement of indigenous and local communities } \\
\text { and co-benefits is recognized }\end{array}$ & 2009 & \\
\hline $\begin{array}{c}\text { At COP16 in Cancun, UNFCC agrees to include } 7 \\
\text { safeguards in REDD+ }\end{array}$ & 2010 & \\
\hline $\begin{array}{c}\text { Agreement on approaches to finance, guidance } \\
\text { provided on reference levels and safeguard } \\
\text { information systems }\end{array}$ & 2011 & \\
\hline Agreement on Warsaw Framework for REDD+ & 2013 & $\begin{array}{l}\text { Indonesian Constitutional Court Decision No. } 35 \\
\text { recognizes the right of indigenous peoples to } \\
\text { manage their lands }\end{array}$ \\
\hline \multirow[t]{3}{*}{$\begin{array}{l}\text { Final adoption of Warsaw Framework at COP } 21 \text { in } \\
\text { Paris, including further guidance on safeguards and } \\
\text { non-carbon benefits }\end{array}$} & 2015 & $\begin{array}{l}\text { Paris Agreement contains } 5 \text { references to } \\
\text { indigenous peoples }\end{array}$ \\
\hline & 2016 & $\begin{array}{c}\text { General Assembly of the Organization of American } \\
\text { States adopts the American Declaration on the } \\
\text { Rights of Indigenous Peoples }\end{array}$ \\
\hline & & $\begin{array}{l}\text { UNFCCC mandates a specific body to consider } \\
\text { indigenous rights }\end{array}$ \\
\hline
\end{tabular}

Issues of deforestation and the rights of indigenous peoples are not local issues, they are intrinsically tied to the survival of our planet and to the politics of human development. With so much at stake, any analysis, proposals or action must acknowledge two fundamental points: 
- Without massive reductions in tropical deforestation, it will be almost impossible to slow climate change enough to keep global temperature rise below $2^{\circ} \mathrm{C}$. Reducing deforestation can be accomplished faster than any other major greenhouse gas mitigation program and is critical to preserving a habitable world. Clearing tropical forests currently represents 11 percent of total greenhouse gas emissions due to human activity. Furthermore, because living trees absorb carbon dioxide, reducing tropical deforestation could contribute up to one-third of the emission reductions needed to keep global temperature rise below $2^{\circ} \mathrm{C}$ (Seymour and Busch 2016).

- We must not reduce tropical deforestation by harming Indigenous Peoples or worsening their conditions. Indigenous peoples deserve the same rights and respect as all other human beings and their ancestral lands stretch over large tracts of tropical forests.

Indigenous peoples do not bear responsibility for the greenhouse gas emissions that are warming the planet, which wealthy industrialized societies generated.

Furthermore, these same industrialized societies are responsible for displacing, exploiting, repressing, and murdering indigenous peoples over centuries. Indigenous peoples' rights to self-determination and autonomy were recognized internationally in the UN Declaration of the Rights of Indigenous Peoples in 2007.

The rest of this paper explores the relationship between REDD+ programs and indigenous rights by looking at the parallel histories of the two movements and discussing the experience with implementation over the last decade. It relies on a review of two bodies of literature - writings at the beginning of the REDD+ program about its potential benefits or harms and subsequent studies of how REDD+ implementation has or has not affected indigenous peoples. It also draws on three commissioned background papers, case studies on how REDD+ has affected indigenous peoples in Guyana, Indonesia and Peru.

After reviewing the status of indigenous peoples and the implementation of REDD+ programs, the paper assesses whether REDD + and efforts to promote indigenous rights are competing or complementary strategies. It argues that the effects of REDD+ on indigenous peoples are fundamentally different when they are paid to national governments for reducing deforestation than when they are paid to local landowners for the opportunity costs of deforestation.

It then reviews country experiences to see how much REDD+ performance payment agreements with national governments have reduced deforestation and affected indigenous peoples. These experiences show that indigenous peoples have achieved tangible political benefits in many countries and internationally by using their leverage over and participation in REDD+ negotiations.

Nevertheless, these experiences also show that insisting on preconditions for REDD+ national performance payments may have inadvertently harmed indigenous peoples by contributing to delays in implementation. The primary factors infringing on indigenous rights are related to the main drivers of deforestation - particularly the expansion of agriculture, mining and settlements-which should be the main targets of REDD+ performance payment programs. Since only one country has successfully curbed 
deforestation on a significant scale, it is impossible to assess how much deforestation could have been avoided by more expeditious implementation of national REDD + performance payments with greater certainty and fewer preconditions.

Finally, the paper concludes that these two movements are fundamentally entwined. The adoption of UNDRIP and the UNFCCC endorsement of indigenous peoples' rights as a precondition for performance payments has made it impossible to imagine a REDD+ program without safeguards. At the same time, implementation of REDD+ programs has created new opportunities for political action and participation by indigenous peoples. Whereas critics fear implementation of REDD+ will harm indigenous peoples, it is the failure of REDD+ programs to influence national action against deforestation which represents the greater risk. The common challenge for both movements today is to refocus attention on the national policies that could address the most severe threats to both indigenous rights and tropical forests - uncontrolled expansion of agriculture, mining, and human settlement.

\section{Indigenous peoples and tropical forests}

Indigenous peoples and the world's tropical forests are intrinsically connected through time and space. The term "indigenous peoples" is itself a socially-constructed category that has evolved over time. However, its core notion of peoples who have been marginalized through forces of colonization and capitalist market expansion is recognizable in almost all cases. This paper will use the term "indigenous peoples" as it is defined in UNDRIP, but exclusively with attention to those indigenous peoples who live in or near tropical forests. This additional qualification raises the possibility of other terms such as "forest peoples" or "local forest communities" which narrow or broaden the concept, but the emphasis in this paper remains on indigenous peoples. Some of the evidence discussed here refers to these other categories and will be explicitly referenced in those cases. This section provides information about the status of indigenous peoples to understand the general conditions of indigenous peoples and the major threats they face.

Indigenous peoples in all countries are generally disadvantaged relative to the rest of the population in terms of income, access to resources, overall individual and social well-being, and legal status. Where data is available, these disparities are immediately apparent. However, good data on the status of indigenous peoples is quite limited. It is typically restricted to specific case studies or one-time surveys in particular countries. International data is predominantly focused on documenting the presence and security of indigenous land rights rather than population well-being. Furthermore, indigenous peoples typically inhabit remote places and are sparsely distributed, limiting the effectiveness of national censuses, public administrative reporting and even standard social survey methods for understanding their legal, social, economic, and environmental status. In countries which do not legally recognize indigenous peoples, they may even be excluded from censuses and remain unclassified by ethnicity or self-identification. For all these reasons, the data presented here should be interpreted with caution given the limitations in terms of measurement, coverage and representativity. 
With these qualifications, current estimates suggest there are 370 million indigenous people in the world, living in 90 different countries. While indigenous people make up 5 percent of the world's population, they represent some 15 percent of those who are extremely poor (Hall and Gandolfo 2016). Indigenous peoples are linguistically and culturally diverse. They speak a majority of the world's 7,000 languages and they are classified in as many as 5,000 different ethnic groups. At least 60 million indigenous people live inside or close to dense forests and are dependent on these forests for their subsistence and income (Chao 2012).

\section{Land tenure}

Land rights, the security of rights, and proper enforcement of rights are generally recognized as the most pressing problem indigenous peoples face today. As of 2016, customary land users claim over 50 percent of the world's area (Oxfam et al. 2016). Land Rights Now, a World Resources Institute (WRI) program, has calculated that customary land users hold legal title to only 10 percent of that claimed land. ${ }^{1}$

The same source demonstrates that indigenous peoples lack secure rights to their lands in most countries. Out of 13 countries with large amounts of tropical forest, only 6 of them require consent by indigenous peoples and local communities before the government or private actors can acquire lands. On the other hand, only 2 countries fail to recognize community rights to land at all or deny indigenous communities the ability to be treated as legal entities for the purposes of land ownership. Countries that provide stronger legal security are not necessarily wealthier ones; countries like Bolivia and Tanzania are at the top of the rankings and score better than countries like Canada, Finland, and Russia. Among the 13 largest tropical forest countries, Bolivia, Colombia, Peru and Venezuela satisfy all the legal forms of recognition surveyed in this study, while the Democratic Republic of Congo (DRC) satisfies none, Indonesia satisfies three, and Angola satisfies only four (Oxfam et al. 2016). Interpreting these indicators, of course, requires acknowledging that these are only de jure indicators; it establishes the legal conditions for respecting such rights but does not assess the degree of enforcement.

While legal security to land is poor, some progress seems to have been made since 2002. An investigation of statutory legal tenure in 52 countries with the highest area of forest cover reported that lands "owned" by Indigenous Peoples and Local Communities increased from 334 million hectares in 2002 to 415 million hectares in 2013; while lands "designated" for Indigenous Peoples and Local Communities also rose from 51 million hectares to 97 million hectares over the same period (see table 2). About three-quarters of this additional area came from government-administered lands, with the remainder from lands controlled by individuals and firms. Thirty-one out of forty countries for which complete data was

\footnotetext{
${ }^{1}$ Wiley (2011) explains the definitions applied. The estimate relies on taking total land area and subtracting lands in private ownership as well as "permanently cultivated lands, urban areas, planted forests, extreme snow, ice and desert areas..." The residual includes forests and rangelands that are held or used by indigenous peoples.
} 
available showed declines in forest area administered by government, largely due to increases in recognition of land rights of communities, individuals and firms (RRI 2014).

Table 2. Statutory Forest Tenure (millions of has.), 52 Countries, $2002 \& 2013$

\begin{tabular}{lccc}
\hline & 2002 & 2013 & Change \\
\hline Government Administered & $2,762.87$ & $2,409.79$ & $-13 \%$ \\
$\begin{array}{l}\text { Designated for IPs and Local } \\
\text { Communities }\end{array}$ & 51.25 & 96.65 & $89 \%$ \\
$\begin{array}{l}\text { Owned by IPs and Local } \\
\text { Communities }\end{array}$ & 333.98 & 415.17 & $24 \%$ \\
$\begin{array}{l}\text { Owned by Individuals and } \\
\text { Firms }\end{array}$ & 413.43 & 397.11 & $-4 \%$ \\
\hline
\end{tabular}

Source: Rights and Resources Initiative. 2014.

Nevertheless, this sense of overall progress is dominated by large amounts of area which changed hands in Brazil, China and India over this period. Relative to national land area, Latin American countries have generally made the most progress. In 2002, 24.4 percent of land area in the surveyed Latin American countries was designated for or owned by indigenous peoples and local communities, rising to 39.1 percent in 2013. By contrast, the share rose from 30.4 percent to 36.6 percent in Asian countries and only 4.2 percent to 5.9 percent in Africa. Countries like the DRC and Indonesia maintain government control over almost all their forests, 100 percent and 96 percent, respectively. Furthermore, these figures are based on statutory recognition. Even when tenure has been designated or granted de jure, indigenous peoples may lack security de facto, due to limited enforcement of laws or corruption.

This broadly positive trend in indigenous access to their lands is countered by another trend. Multinational corporations have been buying land in low- and middle-income countries on a large scale since the 2007-2008 global food crisis (Oxfam et al. 2016). One source has estimated the scale of this trend by documenting acquisitions since 2000 amounting to more than 50 million hectares in 1,532 deals (Land Matrix 2018). This trend is often referred to as "land grabbing" since much of this land, claimed by local communities and indigenous peoples, is transferred out of small-scale agriculture or community use into large scale commercial use and occurs without Free, Prior and Informed Consent (FPIC) (Oxfam et al. 2016). One study looked at 161 of these transactions and found that only 14 percent of them obtained FPIC for the land transfers; another 43 percent entailed some limited form of consultation, with the remainder lacking any consideration of indigenous land rights (Land Matrix 2016). In fact, very few countries even have national laws that require FPIC or other broad consent before land is acquired from indigenous people or local communities; ${ }^{2}$ and

\footnotetext{
${ }^{2}$ http://www.landmarkmap.org/data/ accessed May 15, 2018.
} 
where it is legally required, countries may not abide by those laws. Many countries circumvent their own laws for protecting indigenous rights by applying very narrow definitions of who is covered by those laws. Some groups have succeeded in challenging acquisitions that took place without consultation in national courts, but many governments either ignore such rulings or pass new legislation nullifying them (Oxfam et al. 2016; Lozano 2018).

\section{Health and social well-being of indigenous peoples}

One of the strongest indicators of social well-being is a population's health status, and indigenous people are usually less healthy and die younger than any other population subgroup in their respective countries (Lancet-Lowitja Institute 2016). When national studies disaggregate health outcomes for indigenous peoples, they typically find that this subpopulation has among the highest morbidity and mortality rates for all age groups, lower life expectancy overall, and higher exposure to health risks, such as environmental contamination (Gracey and King 2009). Still, the magnitudes of social welfare gaps in wellbeing vary considerably across countries. Infant mortality among ethnic minorities in Thailand is 6.6 per 1,000 live births compared to a rate of 4.1 per 1,000 live births among the wider population. By contrast, infant mortality among indigenous groups in Peru is 49 per 1,000 live births, about 7 times higher than ethnic minorities in Thailand and almost 3 times higher than the national Peruvian average rate of 18 per 1,000 live births (Lancet-Lowitja Institute 2016).

\section{Violence}

Indigenous peoples are more exposed to violence than other people in their countries for a range of social reasons (e.g., higher rates of alcoholism, mental health problems, cultural dislocation) but also because of economic and political repression. Comprehensive data on politically motivated violence is particularly difficult to obtain, but Global Witness has been tracking violence against environmental activists since 2002. For 2016, they documented 200 murders of people active in defending land claims and the environment in 24 countries, of which 40 percent were indigenous (Global Witness 2017). The true death toll is likely to be much higher due to underreporting in the media. About 60 percent of these cases were documented in Latin America. Similar findings of violent repression are provided by the International Land Coalition which documents forcible evictions, displacement, arrests, harassment, threats, and murder of indigenous peoples, including repression by military and paramilitary forces (Oxfam et al. 2016).

\section{The struggle for rights and recognition}

Indigenous peoples have struggled for their rights and recognition for centuries, through diplomacy, negotiation, treaties, and conflict. In the last hundred years, numerous domestic and international indigenous organizations have been established to promote indigenous peoples' interests and particularly to seek international recognition in forums like the League of Nations and subsequently the United Nations. In countries with tropical forests, some of 
the most prominent of the national organizations include AMAN (Indonesia), AIDESEP (Peru), COIAB (Brazil), and REPALEF (Democratic Republic of the Congo, DRC). They have sought formal observer or voting status in important governance mechanisms, such as the Amazon Fund in Brazil, the REDD Agency in Indonesia, and the Board of the Green Climate Fund. Indigenous peoples recognize that their struggles transcend borders and have established regional organizations like the Coordinator of Indigenous Organizations of the Amazon River Basin (COICA) and global organizations like the International Indigenous Peoples' Forum on Climate Change.

One of the clearest areas of progress for indigenous peoples in recent years has, in fact, come within international agreements and institutions. Until 2007, the main international resource for legal redress by indigenous peoples was the International Labour Organization's "Indigenous and Tribal Peoples Convention," known as Convention 169 and adopted in 1989. Convention 169 established the rights of indigenous peoples to self-determination, explicitly rejecting the assimilationist approach embodied in an ILO convention from 1957. In 2009, Chile's Supreme Court ruled in favor of two indigenous communities (Chusmiza and Usmagama) in a water dispute with a commercial company, affirming the applicability of Convention 169 which Chile had ratified in 2008. Convention 169 represented a significant, but still limited, step toward international recognition of indigenous peoples' rights. It was ratified by relatively few countries and is weakly enforced.

The United Nations began considering indigenous peoples rights almost from its inception and, in 1982, formally began a process which culminated in adoption of the UN Declaration on the Rights of Indigenous Peoples (UNDRIP) in 2007. Governments from 143 countries voted in favor of UNDRIP with only four opposed. The governments which voted against the declaration-Australia, Canada, New Zealand, and the United States-have all subsequently endorsed the declaration. UNDRIP asserts the equality of indigenous peoples to other peoples, affirms their rights to self-determination, and provides guidance on the responsibilities of States with regard to upholding these and other rights. While Convention 169 established a standard requiring governments to ensure "participation and consultation" of indigenous peoples in decisions affecting them, UNDRIP established a stronger standard - that of Free, Prior, Informed, Consent (FPIC). Furthermore, UNDRIP assigns the State with responsibility to ensure FPIC, not private firms or individuals involved in decisions, claims, or disputes.

During the decades in which the UN studied and negotiated recognition of indigenous rights, political movements pressured multilateral institutions like the World Bank and regional development banks 3 to adopt social and environmental "safeguards" which included provisions to require FPIC and other protections for indigenous peoples. These conditions were of particular relevance for infrastructure projects proposed in environmentally sensitive areas such as old growth tropical forest. The World Bank is the most prominent actor in this sphere and, after adopting its first policy on indigenous peoples in 1982, it has successively

\footnotetext{
3 The most relevant regional development banks include the Inter-American Development Bank, the African Development Bank, and the Asian Development Bank.
} 
elaborated and expanded its approach. It adopted an Indigenous Peoples' Policy in 1991 that reflected the new norms embodied in Convention 169 and required "informed participation" of indigenous peoples in relevant projects. In 2005, the World Bank Board adopted an operational policy on indigenous peoples (OP/BP 4.10) which requires borrowing countries to follow a process of free prior informed consultation for any projects affecting indigenous peoples. ${ }^{4}$

Another set of international negotiations that eventually became important to indigenous peoples' efforts to secure their rights were those concerned with climate change. Indigenous groups had lobbied for greater participation in negotiations under the UN Framework Convention on Climate Change since at least 2000. In 2007, in Bali, some advocates for indigenous rights forcefully opposed the outcome of the UNFCCC Conference under the rallying cry of "No Rights, No REDD" because the final draft lacked language on indigenous rights. Other groups saw the benefits of international action to reduce deforestation and gave their support. In 2008, the International Indigenous Peoples' Forum on Climate Change (IPFCC) was established, giving indigenous peoples formal standing and resources to take part in UNFCCC negotiations. However, many groups were further disappointed by the lack of reference to indigenous rights in the outcome of the UNFCCC Conference in Copenhagen in 2009.

Nevertheless, subsequent implementation and negotiation gradually strengthened provisions within REDD+ to protect indigenous rights. First, bilateral and multilateral agencies responsible for financing and implementing REDD+ programs applied their existing safeguards, including provisions for indigenous rights and requirements like FPIC. For example, "Readiness Preparation Proposals" submitted to the World Bank's Forest Carbon Partnership Facility (FCPF) are assessed for compliance with the World Bank's safeguard policies. Subsequent efforts developed a "Common Approach to Environmental and Social Safeguards" for "delivery partners" like the Inter-American Development Bank (IADB) and UNDP which sought to standardize these protections by maintaining "substantial equivalence" with the World Bank's safeguard policies. ${ }^{5}$ Norway's International Climate and Forest Initiative (NICFI) developed numerous agreements to pay tropical forest countries for reducing deforestation which increasingly contained provisions requiring consultation with and progress on land tenure for indigenous groups, and in some cases resulted in formal representation of indigenous peoples on project review boards and national policy committees (Norad 2016; Norad 2017; Lozano 2018; Forstater et al. 2013; Seymour et al. 2015).

Second, the UN Framework Convention on Climate Change (UNFCCC) negotiations eventually recognized and supported indigenous peoples' demands. In Cancun in 2010, the UNFCCC issued decisions regarding REDD+ that included safeguards, among which respecting indigenous rights and the UNDRIP are explicitly noted. The Paris Agreement

\footnotetext{
${ }^{4}$ http://siteresources.worldbank.org/INTSAFEPOL/Resources/Indigenous peoples review august 2011.pdf

${ }^{5}$ https://www.forestcarbonpartnership.org/sites/forestcarbonpartnership.org/files/Documents/PDF/ Jun2011/TF-PC \%20Final \%20Cover\%20Message \%209-June-2011.pdf
} 
adopted at the UNFCCC Conference in 2015 further recognized the importance of human rights in its preambles, with specific language on indigenous peoples. The Conference in Paris decided to create a knowledge-sharing platform for indigenous peoples and local communities which was subsequently endorsed at the Conference in Morocco in 2016. Those meetings also concluded by charging the "Paris Committee on Capacity Building" to address human rights, gender equality, and indigenous peoples' knowledge in its work. In operationalizing the proposal for an international knowledge sharing platform, the UNFCCC established official negotiations in which state parties and indigenous peoples negotiated at the same table. This strengthens the precedent for stronger representation of indigenous groups at forums which have traditionally been reserved exclusively for representatives of national governments.

Another example of progress for indigenous peoples in the international arena comes from the Green Climate Fund (GCF) which was established in 2010 as the official UNFCCC mechanism to finance climate change mitigation and adaptation projects. In 2016, the GCF gave indigenous peoples a voice in its governance structure by approving the appointment of an indigenous peoples' representative as an alternate active observer at Board meetings. In addition, the GCF Board adopted an indigenous peoples' policy in 2018. ${ }^{6}$ While this represents a significant formal step, indigenous peoples' leaders and activists remain critical of the GCF for inadequate safeguards and the absence of an operational window for directly financing indigenous community projects.

\section{REDD+ and tropical forests}

Other than nuclear war, climate change represents the most significant threat to human life on our planet. While global awareness of climate change and its causes is now widespread, the critical role of tropical forests is often overlooked. The transition to carbon-free energy gets significant resources and attention as it should; however, more attention must be given to preserving the worlds' tropical forests. The best chance for slowing climate change enough to limit global warming to $2^{\circ} \mathrm{C}$ requires massive reductions in tropical deforestation (Seymour and Busch 2016).

Net greenhouse gas emissions from deforestation rose from about 4.5 Gt in 1970 to about 5.4 Gt in 2010 - more than the entire GHG emissions by the European Union that year. Today, net deforestation generates about 11 percent of global emissions (see figure 1). Net emissions are the difference between gross emissions due to deforestation and degradation and carbon sequestration due to forest growth. Using satellite imagery and using a definition that any area which changes to less than 30 percent forest cover has been effectively "deforested," tropical forests were being cleared at a rate of about 5.4 million hectares per year in 2002, exceeded 6 million hectares per year since then and affected 8.9 million

${ }^{6}$ https://www.greenclimate.fund/documents/20182/574763/GCF policy Indigenous_Peoples_Policy.pdf/6af04791-f88e-4c8a-8115-32315a3e4042 
hectares in 2015 (see figure 2). ${ }^{7}$ The risk that tropical deforestation could massively increase in any given year is apparent from the 1997-98 forest fires in Indonesia which covered 9.7 million hectares and affected global emissions (see figure 1). Forest fires in Indonesia and Brazil also contributed to an uptick in annual tropical deforestation which reached almost 30 million hectares in 2016 (Weisse and Goldman 2017). Numerous factors, including rising temperatures, are making such events more likely.

Figure 1. Total Annual Greenhouse Gas Emissions by Source, 1970 to 2010

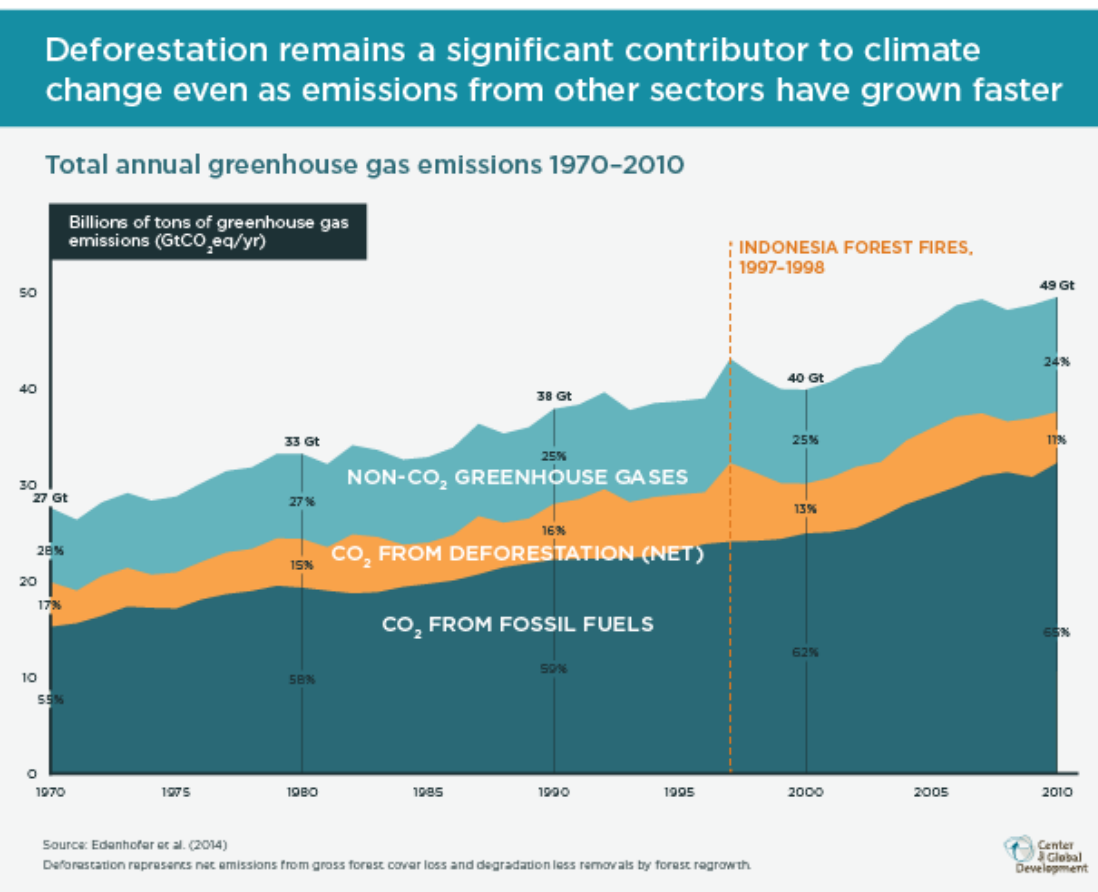

Source: Reproduced from Seymour and Busch 2016.

\footnotetext{
${ }^{7}$ Figure 3 relies on data downloaded from www.globalforestwatch.org referenced as Hansen et al. 2013 which applies a uniform standard to analysis of satellite data. The figures will differ from country-specific reports for several reasons. First, some countries distinguish deforestation of particular regions (e.g. the Amazon) while this data is for all deforestation in a given country. Second, the standard of changing to less than $30 \%$ forest cover is not the same standard utilized by country-specific reports. Furthermore, climatological, biological, and ecological differences across forest biomes means that country-specific reports may be able to interpret satellite data more precisely. Regardless, this data is adequate to provide overall estimates of trends and rough changes in composition for the purposes of this paper.
} 
Figure 2. Deforestation in Tropical Forests, 2002 to 2015

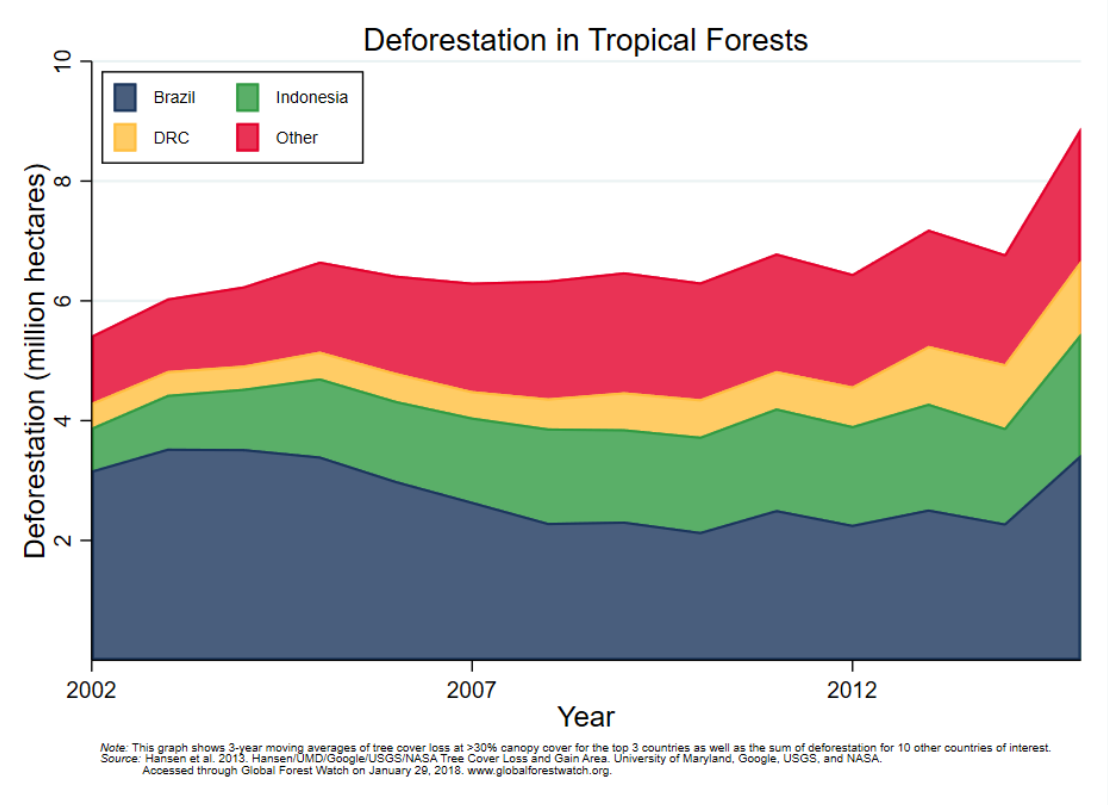

Source: Authors' calculations from Hansen et al. 2013.

Preserving tropical forests is an even bigger part of the solution than it is of the problem. Unlike other sources of greenhouse gas emissions, like burning fossil fuels, preserving tropical forests not only averts new emissions but also sequesters carbon. Intact old growth tropical forests absorb carbon at a faster rate and hold more carbon per hectare than plantations (Brack 2017). As a result, preserving forests would not only eliminate between 8.4 and 10.3 billion tons of gross GHG emissions, but would also absorb an additional 4.3 to 6.2 billion tons per year (Seymour and Busch 2016, p. 43). Furthermore, preserving forests is relatively inexpensive when compared to other ways of reducing GHG emissions. One study conservatively estimated that reaching the $2^{\circ} \mathrm{C}$ target by 2030 would cost 28 percent less if efforts took full advantage of reducing tropical deforestation than without it (Busch et al. 2016). A policy that set a price of $\$ 20$ per ton of averted carbon emissions from deforestation could reduce net emissions by 923 million tons, while a similar policy to induce other mitigation activities in the EU would only achieve reductions of 206 million tons (Seymour and Busch 2016, p. 139).

Preserving tropical forests is not easy because deforestation occurs in spatially dispersed, remote, and often lawless areas. Furthermore, economic incentives to acquire and convert tropical forests to commercial uses are typically quite strong, especially when concessions or purchases can be obtained at minimal cost, either legally or through corruption. A metaanalysis of 121 studies found that economic returns to agriculture were one of the strongest factors driving deforestation, abetted by favorable climatologic and topographic conditions and easier access via roads and other transportation infrastructure. Population pressures and urbanization were also consistently associated with greater deforestation (Busch and FerretiGallon 2017). Human activity also exacerbates forest loss, even when not intended, by increasing the risk of fires. In fact, intact tropical forests almost never catch fire. Rather, fires 
occur when human activity degrades and dries out the forests, making them particularly susceptible in years of high temperatures and drought. The loss of tropical forest cover rose again in 2015 and 2016 in large part because of fires in Brazil and Indonesia (Weisse and Goldman 2017).

Efforts to slow tropical deforestation have to tackle these key drivers or they will fail. While progress can be made in local areas on a case by case basis, national policies are really the key to success (Sunderlin et al. 2013). In fact, without governmental support, many local initiatives will fail. National governments (and sometimes subnational jurisdictions) are the authorities with the instruments necessary to delineate boundaries, assign ownership, enforce regulations, influence land and commodity prices, and plan expansion of public infrastructure in ways that minimize the impact on tropical forests.

We know this is the case from looking at Brazil's experience between 2004 and 2012. Brazil produced the most dramatic reduction in deforestation during that period than has been seen anywhere else in the world. Deforestation in the Amazon fell from 27,772 sq. km in 2004 to less than half that annual pace (12,911 sq. km.) in 2008, and kept declining to 4,571 sq. $\mathrm{km}$. in 2012 , rising more recently to $6,947 \mathrm{sq} . \mathrm{km}$. in $2017 .{ }^{8}$

Critical to that success was high-level political commitment from the President, an active environment minister, and a strong domestic constituency in favor of preserving the Amazon. The government used that support to undertake national policies that included enforcement of existing set-aside provisions, restricting credit to landowners who did not comply with forest conservation laws, demarcating large areas for preservation, and vigorously prosecuting illegal logging and land conversion activities. Unfortunately, the mix of political factors that generated this dramatic success has unraveled in recent years and deforestation has begun to rise again, though it still remains far below the historically high level of 2004.

Brazil's experience also showed that preserving forests did not have to come at the expense of economic growth, agricultural production and development. Soy and beef production particularly relied on clearing forest to expand production for decades. However, in this century because of initiatives to increase productivity, domestic and international public pressures, and eventually threat of prosecution, the soy and beef industries offered voluntary restrictions on selling products from deforested lands. Despite claims that deforestation was necessary for economic development, cattle production grew by 21 percent between 2004 and 2013, while soy production grew by 65 percent. In this same period, overall economic growth was 4 percent annually. While Brazil's success at reducing deforestation while maintaining substantial growth was the result of many factors, it does demonstrate that protecting forests and economic growth can be compatible-especially when public policies establish clear enforceable regulations and market incentives reward producers for increasing productivity (Seymour and Busch 2016, p. 189; Koch et al. 2018).

\footnotetext{
${ }^{8}$ http://www.obt.inpe.br/OBT/assuntos/programas/amazonia/prodes. Accessed May 15, 2018.
} 
Figure 3. Brazilian Deforestation and Agricultural Production, 1995 to 2015

\section{Brazil reduced deforestation and increased agricultural production at the same time}

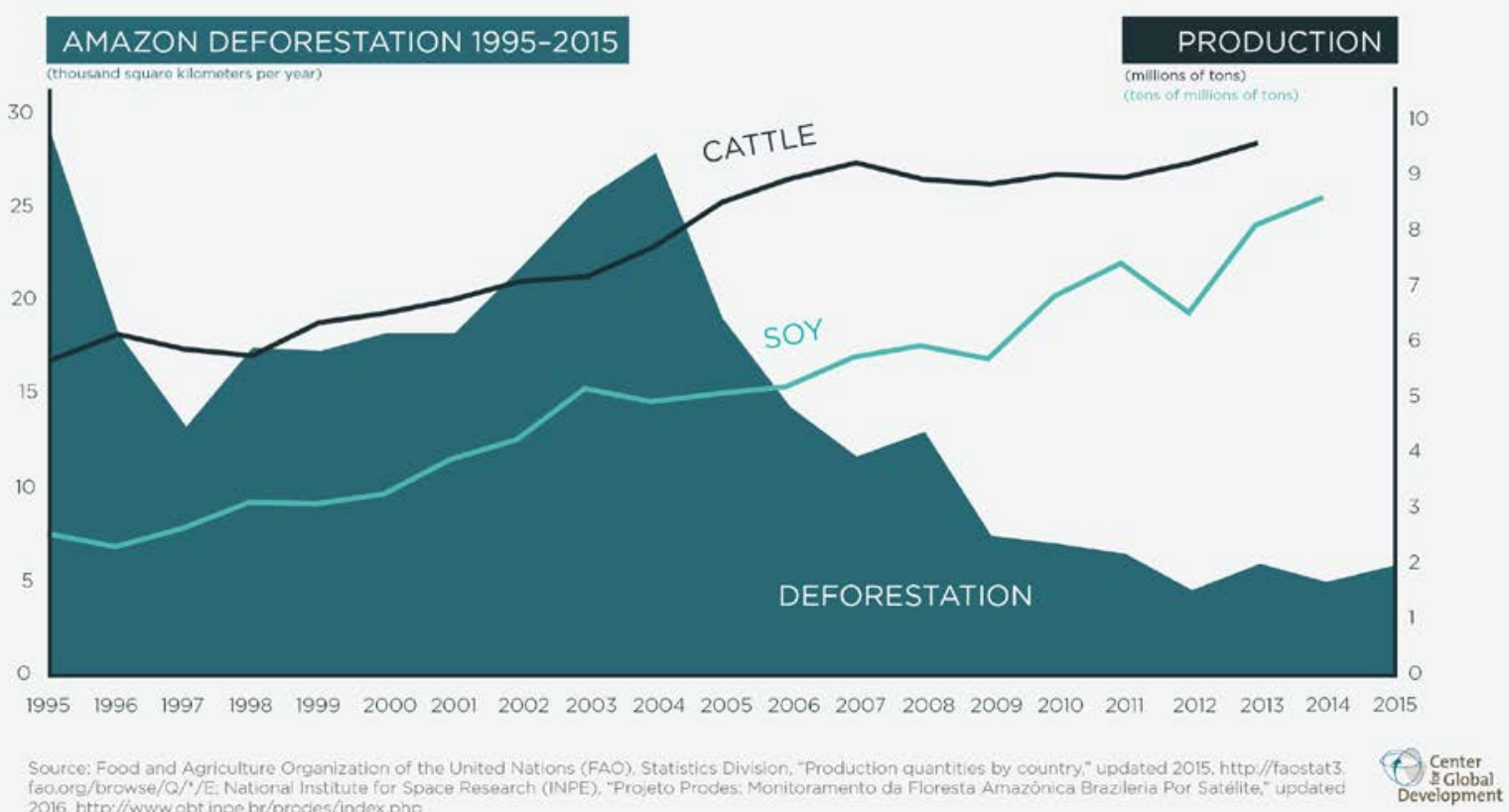

Source: Reproduced from Seymour and Busch 2016.

Brazil's efforts to reduce deforestation grew out of international and domestic concern with protecting forests for a range of benefits including biodiversity as well as climate change. Similar concerns were pressuring international climate negotiators to address deforestation. In 2005, international negotiators were asked by Papua New Guinea and Costa Rica to take up a proposal that would include financial compensation for the reduction of emissions from deforestation. Originally called "Reducing Emissions from Deforestation" (RED), the idea was amended by adding a "D" to include forest degradation and a "plus" to refer to conservation, sustainable management of forests, and encouraging regrowth of forests to sequester carbon. REDD+ was articulated by the UNFCCC in Bali in 2007 and was ultimately endorsed in the 2015 Paris Agreement. ${ }^{9}$

\footnotetext{
${ }^{9}$ For an excellent review of the REDD+ process and negotiations, see Jodoin 2017.
} 


\section{All REDD+ funding is not the same}

At this stage, people use the term REDD+ to refer to a wide range of forest conservation programs. They differ along at least three dimensions: ${ }^{10}$

- What is being paid for?

- To whom is it paid?

- Who pays it?

Regarding the "what," the most prominent feature of REDD+—which distinguishes it from so many other international financial contributions to development-is its intention to pay for outcomes rather than inputs. That is, REDD+ funds are supposed to be disbursed after countries, jurisdictions or landowners demonstrate that they have preserved forests. To the extent that REDD+ pays for verified results, it would differ from most aid programs which tend to pay for inputs—-such as technical assistance, capacity building, equipment, research, and other kinds of activities.

Despite this intention, to date, less than half of the finance considered to be part of REDD+ is results-based (see Figure 4). Most of it is disbursed to pay for inputs that are expected to contribute to reduced deforestation, but which are not results in themselves. The UNFCCC formally recognized the distinction by establishing three categories of REDD+ funding. The first category involves readiness activities, such as establishing institutions to oversee forest conservation policies, monitor deforestation, develop legislation and regulations, and engage in consultation with stakeholders. The second category is for beginning implementation, including experimentation with small-scale results, payments and implementation of policies. The third and final stage enters into force when the country has fulfilled all the conditions to receive payments based on verified reductions in emissions from deforestation and forest degradation, including compliance with social and environmental safeguards.

${ }^{10}$ For a discussion of these three dimensions in relation to performance payments in a cross-sectoral context, see Perakis and Savedoff 2015. 
Figure 4. REDD+ Financing is Primarily Input-Based

\section{Less than half of pledged finance for REDD+ is results-based}

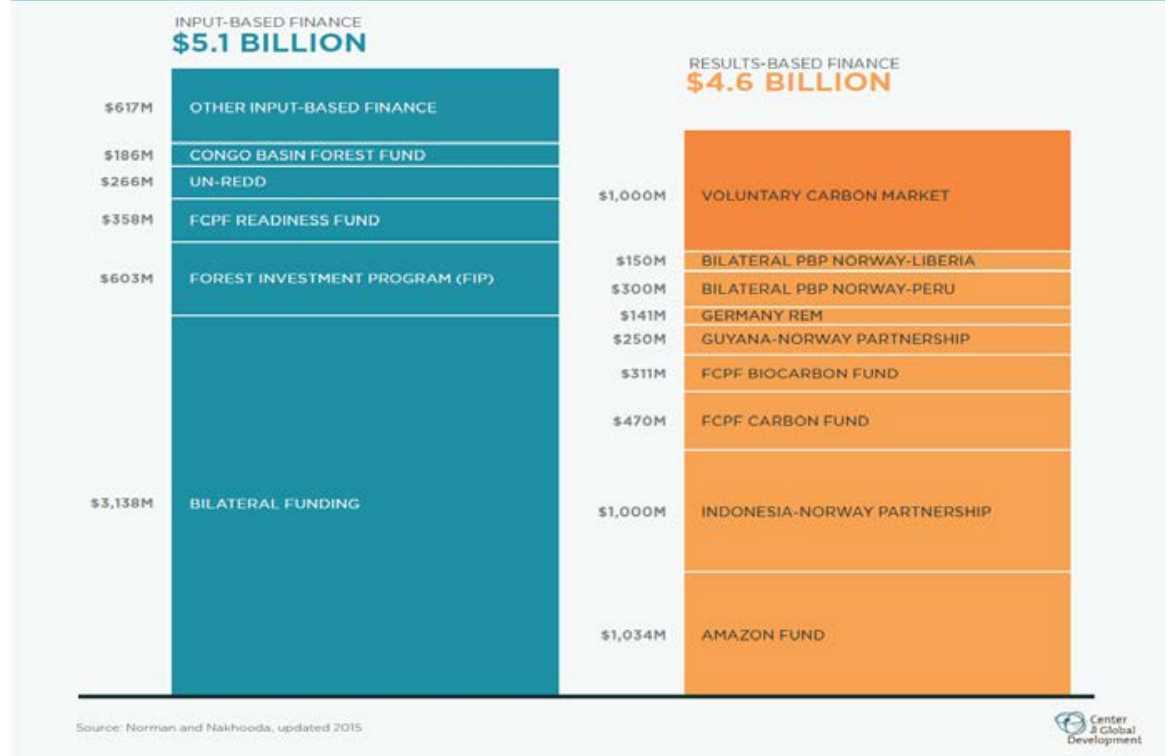

Source: Norman and Nakhooda 2014, updated in Seymour and Busch 2016.

Regarding who gets paid, recipients of REDD+ financing can be national governments, subnational jurisdictions, community groups, landowners, private non-profit organizations, or private for-profit firms. Many national governments have signed agreements under REDD+. The most significant results-based agreements are those between Norway and 11 tropical forest countries. Except for Brazil and Guyana, the governments that have signed these agreements are in the preparatory phases of REDD + and have not received results payments. Other funding going to governments is almost entirely input-based. Subnational jurisdictions have begun to receive funding under REDD+, but again it is mostly inputbased. Prominent examples include Kalimantan in Indonesia, Acre in Brazil, and MaiNdombe in the Democratic Republic of the Congo. The largest number of programs under the REDD+ umbrella are local projects, aimed at strengthening protection of forest preservation areas or engaging communities and landowners in forest conservation initiatives. When these involve payments for results, they are often referred to as "Payments for Environmental Services" (PES), a nomenclature that preceded REDD+. These programs also vary considerably around the world.

Who pays for REDD+? The sources of funds for REDD+ come predominantly from the governments of wealthy countries as bilateral aid or through multilateral agencies. Out of almost $\$ 10$ billion in REDD+ commitments to date only ten percent corresponds to voluntary contributions by private philanthropies or corporations. Part of the explanation for the shift in focus from results payments to input funding is precisely because of the "aidification" of REDD+ (Seymour and Angilsen 2012). When commitments to develop REDD + began in earnest in 2008, most observers expected climate change negotiators to eventually establish binding caps on carbon emissions that would enable a carbon market to flourish. When the cap and trade markets failed to materialize, the only significant funding 
still on the table was coming from countries like Norway and Germany or multilateral agencies like the World Bank, which began to apply their normal approaches to bilateral and multilateral aid relationships.

The logic of paying for forest conservation is not the same for all these programs.

Depending on who pays whom for what, the implications for participants, the environment, and society vary considerably. For example, programs that pay local groups or landowners to preserve forests will not be able to address the broad drivers of deforestation, e.g., the expansion of agriculture or national infrastructure into forested areas. Programs that pay national governments to pass new laws and establish monitoring systems may have little impact on the local enforcement of policies to prevent deforestation or improve indigenous people's land security. Funding from voluntary carbon credits could displace indigenous peoples or benefit them directly depending on the wide range of ways such programs can be designed and implemented. Furthermore, the choice of who receives payments in local communities is itself fraught; it is difficult to establish equitable systems of financial transfers that benefit everyone in a community without disrupting other economic, cultural and power relations within them (Andersson et al. 2018).

Today, the combination of UNFCCC negotiations and the predominance of public and voluntary funding has led to a convergence in approaches on REDD + , the broad outlines of which were laid out at the Conference in Warsaw in 2013. These rules include the phased implementation approach, enumerating rights and safeguards, and providing guidance for procedures like consultations and criteria for reference levels. While these guidelines and principles seek to assure complementarity between the strategies of reducing deforestation and protecting indigenous rights, many people continue to be skeptical of REDD+, arguing that even if it is potentially compatible, its implementation is flawed, distorted by political and economic interests, and harmful.

\section{Competing or complementary strategies? Risk and opportunities of REDD+ for indigenous peoples}

The strategies for reducing deforestation and promoting indigenous rights could be competing or complementary. Much of the literature about REDD+ during its negotiation and before implementation was critical and alert to tradeoffs between these two approaches.

Between 2006 and 2011, we found 43 articles that mentioned REDD+ (or similar terms) and indigenous peoples (see Appendix 3 and 4). The majority of these papers were published between 2008 and 2009, soon after the UNFCCC meetings in Bali. These articles raised thirteen distinct concerns about REDD+ related to: indigenous rights; property rights; problems with monitoring and verification; benefit streams; non-state actors; institutions, corruption, or governance; problematic satellite data; land use; determining appropriate baselines; leakage; transparency/accountability; perverse incentives; and permanence. Of these, indigenous rights were mentioned more often than any other topic, in 25 of the papers. Effects on institutions, corruption, and governance were the next most common (addressed in 23 articles), followed by perverse incentives (19); property rights (16); and benefit streams (14) (See Appendix 3 and 4). 
Regarding indigenous rights, the articles predicted that decision making processes would exclude indigenous people and infringe on their rights to autonomy and free informed prior consent. Many authors argued that the principle of Free, Prior and Informed Consent (FPIC) would be extremely challenging in practice due to asymmetries in power, difficulties of bridging cultural understandings, and the indeterminacy of legitimate representation. Many authors also argued that REDD+ could fragment and disturb indigenous communities by setting up internal competition over financial or political resources. Some authors argued that these problems were inherent to REDD+ because of its commitment to create and pay for tradeable carbon credits. Others viewed the problems as likely but avoidable depending on how the programs were implemented (e.g., Sena 2009).

This critical literature had to rely on projections of how REDD+ might be implemented, without much experience and with the expectation, at the time, that there would be trillions of dollars of carbon cap and trade money creating demand for tradeable carbon credits for application at the project level. As a result, most of this work assumed that payments would primarily be paid to landowners and communities for preserving forests. When assessing the impact of REDD+ on indigenous peoples, then, they tended to focus on how REDD+ implementation at the local level would affect legal status, political participation, land tenure and social well-being. However, they tended to ignore the potential benefits from national actions aimed at the economic pressures for clearing land which tend to be, in most places, the main drivers of both deforestation and rights violations.

Of the 43 studies reviewed, many acknowledge the broader economic pressures to clear forests but typically failed to factor in the potential benefits of REDD+ initiatives in terms of slowing the main drivers of deforestation. Instead, when they considered potential benefits from REDD +, gains at the local level were considered in detail while downplaying or ignoring gains on a national scale from reducing demand for clearing forests more generally. Only one of these studies explicitly considered whether the benefits of national action could offset the local risks of forest conservation efforts. It considered the risk that REDD+ would be unable to compete with the economic drivers of deforestation in Cambodia as a potentially greater threat to forest dwellers than the risks of centralizing forest management (Naughton-Treves and Day 2012).

In other words, most of the criticism of REDD+ initiatives is aimed at the implementation of programs that are designed for and implemented at the local level when the strongest pressures and most important activities require the engagement of national and subnational authorities. This distinction is important because governments are the only actors who can fundamentally alter the main forces behind massive tropical deforestation-economic development and political power. At the same time, paying governments to reduce deforestation influences political power and economic resources in countries by legitimating national action. Finally, the most effective policies within the scope of government action can be entirely compatible with protecting indigenous rights, though it is certainly possible for them to be implemented in ways that violate indigenous rights. 
Whether REDD+ programs are competing rather than complementary to Indigenous Peoples' rights differs dramatically across different designs. ${ }^{11}$ The concerns that REDD+ will infringe on indigenous rights was primarily driven by concerns over the prospect that trillions of dollars of carbon cap and trade money would propel a market for tradeable carbon credits. Failing to clearly delineate indigenous rights as a precondition for such programs inherently risked introducing prohibitions on traditional land use or direct expropriation by the government or private actors. Though this market has not materialized, the attention to these risks has overshadowed the risk to indigenous peoples due to inaction on the main causes of deforestation.

By contrast, REDD+ has evolved with increasing attention to national and subnational policy and action on slowing deforestation. These kinds of actions are likely to support the promotion of indigenous rights wherever the presence of indigenous peoples protects forests and where commercial exploitation and public investment are the primary drivers of deforestation. And these conditions appear to be met in many of the countries and regions experiencing high rates of deforestation (Ding et al. 2016; Busch and Ferreti-Gallon 2017). A national government that responded to such incentives by evicting indigenous peoples would neither reduce deforestation nor receive payments. However, a national government that established protected indigenous areas and restricted commercial exploitation of forests, would benefit from the resulting decline in deforestation by receiving performance payments. Whether these payments should be passed on to people living in the forests depends on whether these performance payments are viewed as a reward to the government for taking effective policy action, a public resource that should be shared with interested constituencies, or a dedicated fund to reinvest in forest protection (e.g., the Amazon Fund).

Nevertheless, national governments and local landowners respond to incentives in many ways, sometimes in direct contradiction to their own interests. Therefore, it is necessary to look empirically at the risks and opportunities which have actually materialized.

\section{Which risks and opportunities have materialized?}

One of the ways to evaluate the impact of REDD+ on indigenous peoples is to distinguish programs that engage national governments-which can influence the main drivers of deforestation-from those which engage local communities and landowners directly. After briefly discussing some experiences with payments to local communities and landowners, this section focuses primarily on national programs that receive payment for reduced deforestation.

\section{Payments to communities, firms, and landowners}

Programs that pay communities, firms and landowners to conserve forests are extremely heterogeneous. Some pay for inputs and activities such as surveying, developing forest management plans, establishing monitoring systems, training, and promotion of alternative

\footnotetext{
${ }^{11}$ See Appendix 2 for a formal representation of the following argument
} 
income-generating activities. Others involve payments based upon the amount of forest cover that is preserved. The effects of these programs on indigenous peoples are equally heterogeneous. They rarely affect legal status of indigenous peoples per se but many do address indigenous peoples' land tenure security within the framework of existing law. They range in terms of the types of consultative processes they utilize and who can play the role of legitimate interlocuter-especially in the case of agreements with indigenous communities. Finally, they affect social well-being by bringing financial resources into indigenous communities and altering behaviors regarding traditional uses of forest lands.

It is beyond the scope of this paper to do a comprehensive assessment of these programs, but it is worth highlighting a number that illustrate the potential benefits and harms associated with such programs. Much of the concern over REDD+ programs is due to environmental programs and forest preservation initiatives that displace peoples or restrict their traditional forms of land use. Though formal policies increasingly preclude eviction, land use restrictions - with or without FPIC - are common to many forest preservation projects. Furthermore, forest projects are frequently implemented in areas where land rights are contested, making it unclear whether forced displacement is attributable to the project or to other factors. In one case, a World Bank investigation of its Natural Resource Management Project for Kenya concluded that the project was not directly responsible for eviction of the Sengwer people, but nonetheless faulted the World Bank for failing to forcefully respond to evictions taking place within the scope of the project. ${ }^{12}$

One of the better sources of data on local communities is based on a 6-country research project $^{13}$ that surveyed 130 villages in a baseline period (2010-2012) and a follow-up period (2013-2014). ${ }^{14}$ Villages were chosen for the study to assure the possibility of comparing communities that would participate in a local REDD+ initiatives with those that would not. One study based on this data (Duchelle et al. 2017) classified different REDD+ instruments into four categories: enabling conditions (such as improved titles or boundaries); disincentives (such as prohibitions on land use or felling trees); incentives (such as payments for hectares of preserved forest or monitoring land use); and mixed use of both disincentives and incentives. The first significant finding was that none of the villages were affected by significant changes in enabling conditions. In other words, the national level actions required to address mapping, land titling, FPIC and respect for rights were largely undetectable at the local level. Second, they found that implementing disincentives left households feeling less secure on their land. Third, the provision of incentive payments did improve household wellbeing, but this essentially offset the negative effects of restrictions. The study also found that households exposed to REDD+ interventions were more aware of local REDD+

\footnotetext{
${ }^{12}$ http://ewebapps.worldbank.org/apps/ip/PanelCases/84\%20- $\% 20$ Investigation $\% 20$ Report $\% 20$ (English).pdf accessed May 16, 2018.

13 The countries included were Brazil, Peru, Cameroon, Tanzania, Indonesia, and Vietnam.

${ }^{14}$ Details on the survey can be found in Sunderlin, W. D., A. M. Larson, A. E. Duchelle, E. O. Sills, C. Luttrell, P. Jagger, S. K., Pattanayak, P. Cronkleton, A. D. Ekaputri, C. de Sassi, R. Aryani, and G. Simonet. 2016.

"Technical guidelines for research on REDD+ subnational initiatives." Bogor, Indonesia: CIFOR; and Sills, E.O., S. S. Atmadja, C. de Sassi, A. E. Duchelle, D. L. Kweka, I. A. P. Resosudarmo, and W.D. Sunderlin, eds. 2014. REDD+ on the ground: A case book of subnational initiatives across the globe. Bogor, Indonesia: CIFOR.
} 
initiatives but did not necessarily have meaningful participation in initiative design and implementation.

Using the same data, another study highlighted the impact local REDD+ projects can have on the distribution of wealth and power within communities (Andersson et al. 2018). It found that villages that initially had greater internal inequality were also those with less tenure security and lower overall wellbeing. When incomes were distinguished by their sources, they found that internally generated incomes were less equally distributed than externally generated incomes (i.e. from REDD+, other forest programs, or public services). This suggests that even at the local level, external involvement through REDD+ initiatives can be progressive, though this comes at the risk of imposing external views on appropriate distribution of resources within communities.

Another study which sought to look at the effects on deforestation and household wellbeing in a local REDD+ project surveyed 60 program villages and 60 control villages in Uganda. This program paid private landholders $\$ 28 /$ hectare for land that they maintained as forested-an amount which compares favorably to the timber value. The deforestation rate for participating landholders was about 4 percent compared to a rate of 9 percent among non-participants. The program was thus successful in terms of reducing deforestation, at a very low cost of $\$ 0.46$ per averted tone of carbon emissions. As for community welfare, the program seemed to have left household incomes unchanged on average- neither benefiting nor harming them (Jayachandran et al. 2017).

Much criticism of REDD+ interventions is based on specific instances of rights violations being alleged in places where REDD+ programs are operating. For example, one study identified 85 articles alleging rights violations related to REDD+ programs (Sarmiento and Larson 2017). This study acknowledges potential bias in that REDD+ projects are often directed to places with land conflicts. However, a further bias is often neglected: that international attention is focused on places with REDD+ programs while rights violations impelled by domestic expansion of agriculture, mining or infrastructure are less likely to be reported. The cases identified in such studies demonstrate the need to fully address land tenure and rights before bringing resources into local communities; however, they do not as yet constitute a systematic critique of the REDD+ process overall.

Local projects have evolved since the earliest days of considering payment for preserving forests. For example, Indonesia's earliest effort to create a legal instrument for preserving forests was created before REDD+ in the form of Ecosystem Restoration Concessions (ERCs) (See Fay \& Dengadurdoss 2018). These concessions gave private enterprises the opportunity to profit from restoring deforested or degraded lands to their natural conditions, initially envisioning revenue streams from voluntary contributions by those interested in environmental conservation and mitigating climate change. Once international climate change negotiators established an action plan for international tradeable carbon credit markets, the ERC looked like a perfect instrument for a market approach to protecting forests; but also raised concerns over land grabs and the likelihood that politically-connected private firms would profit at the expense of indigenous peoples and other local communities. Because international agreements to create carbon credit markets have 
effectively stalled, this potential threat has not seriously materialized. By 2017, only 16 ERCs have been created, covering about 600,000 hectares. Of these, the Katingan Peatland Restoration and Conservation Project located in Central Kalimantan is cited as a model project, both for its restoration and for its attention to free prior informed consent for local communities. Nevertheless, it is an exception and nothing in the ERC legislation requires consideration of local community rights. ${ }^{15}$

\section{Payments to governments}

International payments to governments to reduce deforestation are also heterogeneous, but the existence of international climate negotiations and a limited number of large multilateral and bilateral funders has given these programs certain common elements. Since 2009, REDD+ payments to governments for reducing tropical deforestation distinguish three kinds of funding: for readiness, implementation and performance. Readiness funding supports governments in such activities as developing national strategies and designing forest monitoring systems. Implementation support covers pilot projects, deforestation monitoring and enacting policies like tenure reforms. Countries that have fulfilled certain conditions, become eligible for performance payments which are calculated on the basis of reductions in deforestation relative to a reference level. The single exception to this pattern is the Amazon Fund, which was established by agreement between Brazil and Norway, and which operated as a performance payment program from its inception-in large part because Brazil's proposal established credible instruments and policies for monitoring and controlling deforestation, as well as institutions for addressing fiduciary and social risks (Birdsall et al. 2015; Abranches 2015).

To date, most REDD+ funding has been allocated for readiness and implementation activities and, in this regard, differs little from conventional input-based forest programs. Governments receive grants or loans to finance inputs and activities such as legislative action, regulatory design, public consultations, forest monitoring, forest service training and equipment, mapping, land titling, community organization, extension services to intensify agricultural production on existing lands, and engineering designs that reduce the impact of mining or infrastructure on forests. Such programs are likely to be effective in countries where governments are committed to making them work and in which they address the real drivers of deforestation. However, many of these projects fail when domestic resistance arises, political commitment is lacking, or analysis fails to identify the real causes of deforestation.

\footnotetext{
15 One such example is the Hutan Harapan (forest of hope) project by PT REKI. For an overview of the conflict, "Hutan Harapan Forest Conflict, Jambi, Indonesia." Environmental Justice Atlas. https://ejatlas.org/conflict/reddconflict-in-jambi-indonesia and "Harapan Rainforest conservation project urged to respect indigenous peoples' rights.” Forest Peoples’ Programme. https://www.forestpeoples.org/en/region/indonesia/news/2013/06/harapan-rainforest-conservation-projecturged-respect-forest-peoples-r
} 
One key aspect of performance payments is to acknowledge that funders do not know the "right" technology, instruments, or issues that need to be addressed to achieve success. In the case of paying for reduced deforestation, most governments will need to confront vested interests and politically powerful groups which benefit from the status quo. International funders have no way of directly supporting action against those interests, but by giving performance payments to the tropical forest country government, they may provide resources or political cover for domestic actors who do want to make progress. This is essentially the story of how payments to the Amazon Fund reinforced and amplified the domestic coalition for forest conservation in Brazil (Abranches 2015). It is important to recognize, therefore, that performance payment agreements cannot guarantee success. They only create the conditions that reveal whether countries are making the commitments-in terms of funding, personnel, and political choices - that yield progress. Depending on the design of the performance indicator, the quality of this signal of commitment may be attenuated by the influence of other factors or by choosing particularly easy benchmarks.

When performance payment agreements are introduced without conditions, they can begin to operate immediately. The introduction of conditions which may all look reasonable from outside the country — such as developing a plan, engaging in consultations, undergoing training, or establishing a new agency—may actually delay a program by diverting managerial and political attention away from confronting the policies and practices which support and encourage large scale deforestation. When such conditions are truly necessary, the delay may be justified. But when such conditions are based on undue caution or unmerited concerns, the costs in delay are problematic. In the case of forest programs, including human rights provisions into REDD+ agreements is understandable given past experience with programs that violated indigenous peoples rights. However, to the extent protections for indigenous peoples are compatible with reduced deforestation, are these human rights conditions helpful? And even if the conditions were helpful, do the consequent delays in paying governments for national action on the main drivers of deforestation end up hurting indigenous peoples by slowing the very actions needed to preserve their forests from commercial exploitation?

One way to answer such questions is through case studies. A comparative perspective can reveal something about the way domestic political processes, international negotiations, program design, and human rights conditions affect progress on reducing deforestation and protecting indigenous peoples' rights. The comparative approach is less effective analytically, in this case, due to limited variation in the design of national performance payment programs and the limited range of actions taken by tropical forest countries. Nor are there clear successes to be contrasted with failures. Still, comparing experience with implementing REDD+ national programs across different countries and context reveals certain dynamics that will help answer how these programs have affected indigenous peoples and whether alternative approaches would be better for them.

Five tropical forest countries have been selected to illustrate the range of contexts in which REDD + performance programs have been initiated: Brazil, Guyana, Indonesia, Peru and the Democratic Republic of the Congo (DRC) (see table 3). Other than containing large tracts of tropical forest, the only other common feature these countries may share is the extent to 
which indigenous peoples are marginalized politically, socially and economically. The indigenous peoples themselves are heterogeneous culturally and ethnically. The drivers of deforestation are also diverse-with palm oil and logging predominating in Indonesia, gold mining in Guyana, small-holder agriculture in Peru, expansion of soy and beef production in Brazil, and itinerant slash and burn agriculture in the DRC (though this is poorly studied and contested by other reports, e.g. DRC 2012). Political commitment to addressing deforestation and indigenous rights also varies substantially across these countries. The political coalitions in favor of reducing tropical deforestation have been strongest in Brazil, much weaker in Guyana, Indonesia and Peru, and are weakest of all in the DRC, where security and the reach of the state are quite limited.

Table 3. Five Tropical Forest Countries, Selected Characteristics

\begin{tabular}{|c|c|c|c|c|c|}
\hline & Brazil & Guyana & Indonesia & Peru & Congo (DRC) \\
\hline Indigenous Peoples Population & 817,963 & 78,492 & 50-70 million & 332,975 & $100,000-600,000$ \\
\hline Legal Recognition (10 = top score) & 9 & 9 & 3 & 10 & 0 \\
\hline $\begin{array}{l}\text { Major Indigenous National } \\
\text { Organizations }\end{array}$ & COIAB & APA & AMAN & AIDESEP, CONAP & $\begin{array}{l}\text { LYNAPICO, } \\
\text { REPALEF }\end{array}$ \\
\hline Land tenure (share of forest) (2002) & $13 \%$ & $0 \%$ & $0.60 \%$ & $1.20 \%$ & $0 \%$ \\
\hline \multicolumn{6}{|l|}{ Forests $(1,000$ s of hectares) } \\
\hline Total Forest Cover (2000) & 519,188 & 18,996 & 160,975 & 78,069 & 199,224 \\
\hline Annual Forest Cover Loss (2001-2008) & 3,098 & 7 & 1,105 & 104 & 431 \\
\hline Annual Forest Cover Loss (2009-2016) & 2,699 & 12 & 1,780 & 192 & 884 \\
\hline \multicolumn{6}{|l|}{ Funding (US\$ millions, cum. as of 2017) } \\
\hline Total REDD+ funding & 2,240 & 260 & 1,700 & 546 & 514 \\
\hline Date of 1st Norway Agreeement & 2008 & 2009 & 2010 & 2014 & 2016 \\
\hline Results Payment Commitments & 1,279 & 250 & 1,000 & N/A & 50 \\
\hline Results Payments Disbursed & 1,218 & 190 & $\mathrm{~N} / \mathrm{A}$ & $\mathrm{N} / \mathrm{A}$ & - \\
\hline
\end{tabular}

Notes: Peruvian population figure is for Amazonian lowland indigenous peoples only. Forest cover loss figures are based on University of Maryland data on areas that change to less than 30 percent tree cover for all forests in the country. This differs from "deforestation" because it also includes natural causes like fires. It differs from other figures in the paper due to geographic coverage being for the entire national area and not just specific tropical regions, e.g. for all of Brazil and not just the Amazon.

Sources: IBGE, Brazil, 2010; IWGIA 2018; Lozano 2018; Laing 2015; Ben-Achour et al 2011; White and Martin 2002; Bastida et al. 2017; Wolosin et al 2016; Johns 2015. See Appendix 1 for more detailed information.

\section{Brazil}

Brazil's experience shows that domestic political mobilization of indigenous peoples within domestic political coalitions had substantial impact on indigenous rights before REDD+ came into existence. From 2002 to 2013, the share of lands designated for or owned by indigenous peoples and local communities more than doubled in Brazil, from 18 percent to 27 percent (RRI 2014). Most of this increase began during President Lula's administration and particularly during the tenure of Marina Silva as Environment Minister from 2003 to 2007. However, Brazil's international agreement to receive contributions from Norway for reducing forest-based emissions still established new precedents and benefits for indigenous 
peoples, most specifically in terms of representation on a committee that oversees the national development bank's administration of the Amazon Fund and access to specific grants and credits within that program. International pressure is still of importance to domestic political decisions regarding the Amazon and indigenous peoples, though Brazil's current political crisis has weakened both the government's capacity and resolve to continue its aggressive campaign to slow deforestation. Still, Brazil's experience from 2000 to 2012 shows that drastic reductions in deforestation are possible when a national government pursues policies to protect indigenous lands, enact stricter controls on licensing economic activity, enforce land rights, police illegal activities, limit infrastructural expansion into forested areas, encourage intensification of agriculture on existing lands, and limit the impact of mining and other extractive activities on forests. This comprehensive set of government actions benefited specific groups of indigenous peoples by recognizing their land tenure and rights, but further benefitted indigenous peoples as a whole by avoiding deforestation that would otherwise have occurred due to agricultural, mining, and settlement expansion.

\section{Guyana $^{16}$}

Guyana is much smaller than the other countries discussed here. It has a population of about 750,000 and contains only 18 million hectares of tropical forest-even though this covers some 84 percent of its territory. Most of the population lives on a narrow coastal strip where economic activity related to sugar and rice plantations has dominated, while the Amerindian peoples in the interior historically lived apart from the market economy. Data from the 1990s shows a very low rate of deforestation - about 0.01 percent each year. It is only since the 1990s, with a return to democracy and a revival of the economy, that Guyana has had significant expansion into the forests for extracting timber, gold and diamonds. This has increased communication with many indigenous communities, bringing them into the cash economy and increasing their political involvement. Deforestation has also increased, reaching a peak of 0.08 percent in 2012 before falling off again to 0.07 percent in 2014 .

Unlike Brazil, then, Guyana has a historically low rate of deforestation and faces a different policy challenge: assuring a development path which keeps this rate low. While most governments have treated tropical forests as a source of economic growth through expanding agriculture, mining, and timber extraction, President Bharat Jagdeo took a different approach and sought to capitalize on international interest in preserving tropical forests. As early as 2006, he offered to put his country's tropical forests into service in "the world's battle against climate change" if he could find willing partners (Stabroek News 2007). Contacts with the United Kingdom were not fruitful, but during this period, Norway was expanding its engagement with REDD+. Its agreement with Brazil in 2008 and parallel developments in international climate change negotiations made Guyana an attractive partner for Norway's efforts. In 2009, the two countries signed a Memorandum of Understanding with the goal of encouraging "sustainable low carbon development" and establishing a framework for "results-based Norwegian financial support to Guyana's

16 This section draws primarily from Laing 2018. 
REDD-plus efforts." 17 The Joint Concept Note which followed included a Norwegian commitment of up to $\$ 250$ million over five years in return for Guyana keeping its deforestation rate below a target of 0.275 percent and establishing the conditions for planning, policy consultations, and respect of indigenous rights.

The initial excitement, and fears, over REDD + funding opened political channels and funding sources for indigenous communities that did not previously exist. The government initiated an unprecedented consultation process in 2009 over two months and involving more than 3,000 people in 15 separate events. The government created a Multi-Stakeholder Steering Committee (MSSC) whose mandate eventually encompassed the whole national Low-Carbon Development Strategy (LCDS). The Amerindian Peoples' Association (APA), Guyana's largest indigenous peoples NGO, refused to join the process until clearer terms of reference were provided (which never occurred) (Laing 2015). The consultation process had numerous problems and was criticized for, among other things, not being realistic about the availability and potential uses of funding, the timeframe for improving land tenure, and the openness of the government to responding to inputs. Nevertheless, the process was on a larger scale than anything previously attempted and was far different from Guyana's historical approach to making public policy without the participation of indigenous peoples. Combined with the growing political mobilization of indigenous peoples in the last decadeincluding the emergence of indigenous peoples as a pivotal voting constituency between the country's large Afro-Guyanese and Indo-Guyanese blocs-the consultation process set in motion by the Guyana-Norway agreement strengthened indigenous political action to claim their rights.

Despite the initial excitement, REDD+ seems to have had minimal effects on Guyana's forests and indigenous peoples due, in part, to its slow and imperfect implementation. While the Norwegian agreement with Brazil relied on a range of existing institutions and began to disburse performance payments within a year, the agreement with Guyana included a series of preparatory activities related to monitoring deforestation, public consultation, and creating a new institutional mechanism for channeling funds. Initial delays appear related to the involvement of the World Bank which had been appointed to manage the newly-created Guyana REDD+ Investment Fund (GRIF).

Another reason for delayed implementation is the sequence of overlapping requirements before funds can be disbursed. Maintaining the deforestation rate below 0.275 percent is only a precondition for disbursement which requires, in addition, satisfaction of a number of safeguards related to fiduciary, environmental and social conditions, as well as the approval of projects which would utilize the funds. Both Norway and domestic civil society groups like APA supported these conditions as a way to assure that funding would be used appropriately, but this came at the cost of delaying disbursements and implementation. This

\footnotetext{
${ }^{17}$ The Government of the Cooperative Republic of Guyana and the Government of the Kingdom of Norway, 2009.

https://www.regjeringen.no/globalassets/upload/md/vedlegg/klima/klima skogprosjektet/the-memorandumof-understanding-guyana-norway-on-redd-081109-signed-091109.pdf
} 
kind of "double demand" is common in REDD+ programs which have taken on the logic of aid projects and their emphasis on paying for inputs. Performance payments in such programs end up being an additional hurdle rather than an alternative to inflexible preplanned activities. Due to these delays, the Amerindian Development Fund was not established until 2012 and the land titling program didn't start until 2013. The program that allows indigenous communities to "opt in" to receiving forest conservation payments for local community projects has yet to begin other than a single pilot initiative in the community of Muritao. This has led to significant disillusionment among indigenous groups and skepticism over receiving any benefits under the LCDS and REDD+.

The impact of REDD+ national funding on deforestation has also been limited, due to strategic errors and changing conditions. The government's strategy for keeping deforestation rates low_-as endorsed by the Memorandum of Understanding and Joint Concept Note-was to forestall widescale expansion of agriculture and settlements into the forest by promoting economic growth in sustainable low-carbon economic activities on the coast and building a large hydroelectric project at the Amaila Falls. The consulting report that supported this approach had widely overestimated the likely rate of deforestation and entirely missed what turned out to be the most significant driver of deforestation during this period: gold mining. Between 1990 and 2005, when international gold prices ranged around $\$ 400$ /oz., Guyanese gold declarations were about 100,000 oz./year and deforestation on Amerindian lands was below 200 hectares annually. By 2012, however, when gold prices were over $\$ 1,600 /$ oz., Guyanese gold declarations exceeded 450,000 oz. and deforestation on Amerindian lands had risen to more than 1,000 hectares (Laing 2018). Another unforeseen event was the discovery of large offshore petroleum reserves which promise new revenues that would dwarf those related to REDD+.

Guyana's government had strong high-level commitments to reducing tropical deforestation and initially made substantial progress in negotiating international programs to benefit from international interest in forest conservation. However, implementation was slow and conditions changed. Consequently, the impact on indigenous peoples and deforestation are minimal. Fears that paying for forest conservation would alter the relationship between indigenous communities and the forest failed to materialize because project funding never arrived.

The most lasting impact of the national REDD+ program has been its influence on Guyana's national politics as a result of the public consultations and efforts at policy development. In particular, climate change, the importance of tropical forests, and the imperative of consultation with indigenous peoples are now part of the national discourse. Though the LCDS was closely identified with President Jagdeo and his party (PPP-C), the current government under President David Granger and an opposing coalition (APNU and AFC) has issued a Green State Development Strategy which preserves the main elements of the LCDS and is funded in large part through the GRIF. 


\section{Indonesia $^{18}$}

Indonesia has made slow but important progress toward acknowledging both the need to preserve its tropical forests and to protect the rights of its indigenous peoples. When REDD+ programs were taking shape in 2007 and 2008, indigenous groups opposed them, fearing that the Indonesian government would treat carbon stocks in forests as simply one more commercial resource to be extracted from the forests without regard to the peoples who live there. These fears were well-grounded in a country which had for decades treated forests as the State's exclusive preserve for economic exploitation by favored interests and with no consideration for the claims of indigenous peoples. Indeed, the Ministry of Forestry's initial regulations for carbon stocks envisioned concessions-much like those for logging — and made no mention of the rights or interests of indigenous peoples.

Indonesia has the world's third largest tropical forest and accounts for more greenhouse gas emissions from deforestation than any other country in the world. When massive forest fires broke out in 1997 and again in 2015, Indonesia's greenhouse gas emissions rose spectacularly, leading to a noticeable jump in overall emissions worldwide. between 2001 and 2016, 23.1 million hectares of tropical forest were cleared, burned or degraded. ${ }^{19}$ In fact, Indonesia's emissions just from deforestation-about $200 \mathrm{Mt}$ of CO2 emissions in 2016-are larger than the total emissions from countries like the Netherlands or Belgium.

Indonesia also has somewhere between 50 and 70 million indigenous people across its archipelago of islands. Indonesia's policies toward these indigenous peoples are contradictory. While Indonesia signed UNDRIP, it has also argued that provisions of that declaration are inapplicable because, it claims, all Indonesia's people are indigenous. Indonesia's constitution and laws recognize groups of self-identified indigenous peoples who have non-transferable communal land rights in perpetuity, but Indonesian governments have also regularly ignored traditional land claims in favor of issuing concessions for commercial exploitation of forests.

In this context, Indonesia's progress in trying to regulate forest management, to demarcate and protect land tenure, and to respond to indigenous participation in policymaking and local land decisions is notable. Two overlapping movements account for this changed tenor of political discourse-domestic mobilization and action by indigenous peoples and international pressure from governments, agencies, and NGOs concerned with the environment.

\footnotetext{
${ }^{18}$ This section draws primarily from Fay and Denduangrudee 2018. Jodoin 2017 provides a comprehensive treatment of REDD+ and indigenous rights, in comparison with Tanzania, from a legal and sociological perspective.

${ }^{19}$ Global Forest Watch measures tree cover regardless of whether those trees are part of a planted forest or a natural forest, making it difficult to determine an accurate measure of "wall to wall" conversion of natural tropical forests in Indonesia
} 
Indigenous peoples in Indonesia have organized and mobilized to claim their rights through domestic channels (e.g. direct lobbying, elections and lawsuits in the courts) as well as international channels (e.g. claims filed with the United Nations Committee on the Elimination of Racial Discrimination in 2009). But Indonesia's indigenous people have played a role in international organizations as well. The National Indigenous Peoples' Alliance of the Archipelago (AMAN) is probably the world's largest indigenous peoples' organization, representing some 2,332 communities and an estimated 17 million individuals. AMAN participated in the 2007 REDD + negotiations and along with other civil society groups protested when rights language was excluded from the Bali Plan of Action. AMAN has been one of the most prominent organizations advocating for addressing rights in international negotiations on reducing deforestation.

The second movement, the environmental movement aiming to slow climate change and reduce tropical deforestation, got high-level attention in Indonesia when it hosted the 2007 UNFCCC conference in Bali. That conference increased the salience of deforestation as a policy issue to the government and subsequently, in 2009 at a G-20 meeting in Pittsburgh, President Yudhoyono made a voluntary commitment, the first by a developing country, to a specific target for lowering greenhouse gas emissions. Yudhoyono pledged that Indonesia would reduce emissions by 26 percent on its own, but further offered to reduce emissions by 41 percent if Indonesia were to receive international assistance. When Norway agreed to fund such an ambitious plan, the resulting agreement between the two countries included language requiring consultation with people affected by deforestation programs and specifically mentioned indigenous peoples. Indonesia's commitment to international climate negotiations and its bilateral agreements have therefore given indigenous peoples opportunities to pressure the Indonesian government for greater participation in national policy setting and local land use decisions.

Despite this progress, the results of Indonesia's participation in REDD+ are still predominantly focused on establishing the conditions for reducing deforestation and protecting indigenous rights rather than affecting outcomes. In terms of protecting its tropical forests, Indonesia signed a Letter of Intent with Norway in which it agreed to a moratorium on new forest concessions. That moratorium was eventually enacted despite strong opposition within the government but weakened relative to the proposal negotiated by the government's REDD+ office. Indonesia later created a REDD+ Agency to coordinate forest policies, to promote environmental protection and participatory consultations, and to oversee creation of "One Map" that would help reveal and resolve overlapping land claims. However, this agency was eventually subsumed by the new Jokowi administration in 2014 within a new Ministry of Environment and Forestry, raising questions regarding its continued relevance and authority. Though Indonesia has made progress in establishing new frameworks, legislation, policies and institutions to address tropical deforestation, the practical effects are not apparent. The gravest indication of all is the continuing high rates of deforestation; in 2016 alone, another 2.1 million hectares were deforested. ${ }^{20}$ Based on

\footnotetext{
${ }^{20}$ www.globalforestwatch.org accessed May 15, 2018.
} 
satellite data, about 14 percent of Indonesia's tropical forest in 2000 has now been deforested or degraded (Hansen et al. 2013).

A similar case can be made for indigenous peoples. They have achieved important progress in legislation, the courts, and in public consultation, much of which can be attributed to the "transnational legal process for jurisdictional REDD+" (Jodoin 2017). Some signs of progress include:

- Requirements in the Norwegian Letter of Intent and the Joint Concept Note negotiated with Norway and Germany to require consultation with indigenous peoples.

- Governmental recognition of indigenous peoples' organizations in consultations over forest policy under the REDD+ Presidential directorate and REDD+ Agency, along with developing ongoing relationships between government officials and AMAN.

- A "National program of recognition and protection of indigenous and tribal peoples under the REDD+ program" endorsed by Indonesia's Vice President.

- Supreme Court recognition of indigenous rights in an important legal case which was plausibly influenced by mapping initiatives undertaken as part of the REDD+ effort.

- The first time indigenous rights have been included in the platform of a government (introduced by the Jokowi administration).

- In December, 2016, for the first time, Indonesia recognized communal tenure for 9 communities on 13,000 hectares-a small step but establishing an important precedent which was followed by recognition of communal tenure for an additional 9 communities the following year. ${ }^{21}$

Still, practical gains are materializing slowly. For example, the World Bank estimated that rights to nearly 25 million hectares of forest involving thousands of villages remain unsettled; and AMAN has estimated that 81 percent of community-created maps overlap with areas claimed by the State to be under its control.

The confluence of the domestic indigenous rights movement and the international environmental movement have led to important changes to legislation, court decisions and policies regarding forests and indigenous rights that look quite different than was the case ten years ago when forest conservation policies looked antithetical to indigenous rights. While deforestation in Indonesia continues apace and indigenous rights continue to be violated, progress is being made through exploiting the complementarities between REDD+ and the growing political mobilization of indigenous peoples. The question is how fast these preparatory efforts will be translated into outcomes.

\footnotetext{
21 https://news.mongabay.com/2017/01/jokowi-grants-first-ever-indigenous-land-rights-to-9-communities/ Accessed April 21, 2018 and https://news.mongabay.com/2017/11/indonesian-president-recognizes-landrights-of-nine-more-indigenous-groups/ accessed June 20, 2018.
} 


\section{Peru $^{22}$}

Peru has played an active role in international negotiations on preserving tropical forests and made significant international commitments to protect its forests. Yet, its economic model continues to rely on economic sectors, particularly agriculture, mining, and energy, which are driving deforestation. In addition, the country's forestry policies still encourage maximizing the extraction of economic value. These inconsistencies in forest policy and management strategies raise doubts over Peru's political will and ability to reduce the pace of forest loss.

Peru has the fourth largest tropical forest area in the world. Most of Peru's tropical forests are controlled by the State which has allocated 41 percent of them (28.4 million has.) for permanent or future economic use and another 17 percent (13 million has.) to indigenous communities under communal titling (for agriculture) or concessions with use-rights (in forests). However, indigenous groups claim an additional 20 million hectares that are occupied and used traditionally (Espinoza and Feather 2011).

Peru's rate of deforestation has been limited until recently because most of the country's population and economic development has taken place on the coast and is separated from the Amazon basin by the Andes. Nevertheless, deforestation has risen quickly-from less than 100,000 hectares per year from 2000 to 2004 up to 164,662 hectares in 2016. This deforestation is mostly due to land use change from forest to agriculture, mining and infrastructure (MINAM, 2015b). Despite Peru's stated commitment in Copenhagen in 2010 to reach zero net emissions from land use change and forestry by $2021^{23}$, its environment ministry projected a secular rise in deforestation of about 3 percent per year through 2030 (see figure 5). The MINAM report is both an indication of the lack of coordination in national policies and a tacit recognition that existing policies are not being implemented in a way that would alter current trends (MINAM 2015a).

22 This section draws primarily from Lozano 2018.

23 Piu, H.C. and Menton, M., Contexto de REDD+ en Perú: Motores, actores e instituciones. Documentos Ocasionales, Bogor, Indonesia: CIFOR, 2013, http://www.cifor.org/publications/pdf_files/OccPapers/OP_90.pdf. 
Figure 5. Deforestation in Peru, Historical and Projected (hectares)

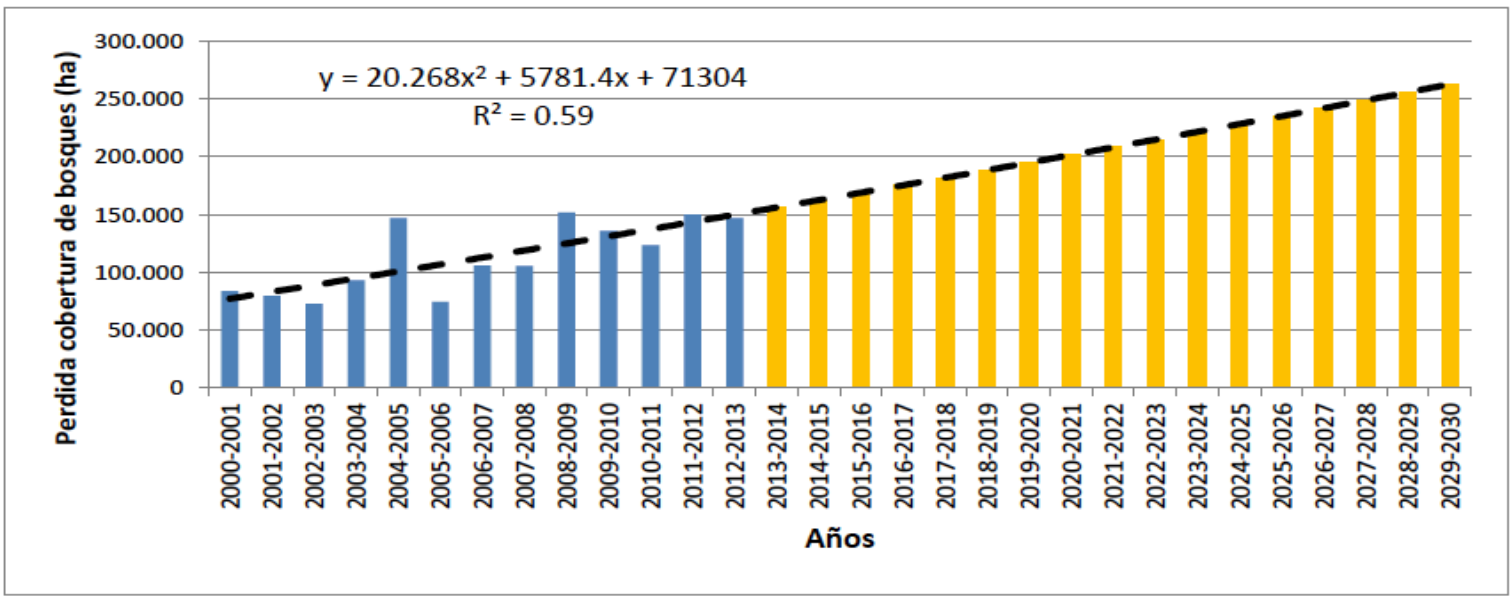

Source: Reproduced from MINAM, 2015a

At the same time, Peru has a longstanding history of repressing and exploiting indigenous peoples of the Amazon since colonial times. The country's national policies treated the Amazon region as a resource to be exploited and its indigenous inhabitants as obstacles or source of labor. In 1974, a left-leaning military government gave indigenous peoples rights to their land that could not be alienated, seized or proscribed. ${ }^{24}$ However, later developments circumscribed these rights. The 1979 Constitution qualified these rights by allowing the State to expropriate lands in the public interest and the 1993 Constitution simply revoked the inalienability and protections against seizure of indigenous lands (Chuecas, 2009).

In the 1970s, indigenous communities who had mobilized locally to protect their land began to group in regional organizations, eventually founding a national federation in 1979 which became the Asociación Interétnica de Desarrollo de la Selva Peruana (AIDESEP). Today, almost all lowland indigenous communities are members of one of two federations: AIDESEP has 1,350 communities, 75 local federations and nine regional organizations, while the Confederación de Nacionalidades Amazónica del Perú (CONAP) has 30 local federations in five regions (Yashar, 2005).

Efforts by AIDESEP and CONAP achieved some progress under President Toledo (2000 to 2006) who signed laws recognizing indigenous traditional knowledge and the rights to intercultural bilingual education. But it was not until an uprising in the Bagua region (20062009)—referred to as the Baguazo — that demands for communal land tenure rights resurged. Indigenous peoples mobilized against President Alan García's government when it enacted land decrees without consulting them. The government responded with violence, leading to 33 deaths, but subsequently capitulated and revoked the decrees. Since that time, the indigenous movement has continued to pressure for greater participation in national policy debates along with progress on recognition of their land claims. One result was passage of a

${ }^{24}$ In Spanish, "tierras comunales eran inalienables, inembargables e imprescriptibles." 
reform in 2011 which enacted the Law of Prior Consultation of Indigenous or Original Peoples.

International developments have given this domestic movement additional political resources through the adoption of UNDRIP, but also, quite significantly, through the conditions attached to forest conservation programs. Almost half of Peru's greenhouse gas emissions are caused by changes in land use and deforestation mostly occurs in areas without clear land titling (MINAM 2015b). Hence, to reach national climate commitments, Peru must solve the tenure agenda by titling lands, allocating rights, enforcing laws, and improving monitoring and supervision. International support to such programs comes tied to requirements that the government consult with local populations and respect their traditional rights to land.

Peru has willingly adopted many of these programs by taking a leadership role in international discussions on tropical forest conservation. At the Copenhagen conference, in 2010, Peru publicly committed to achieve zero net emissions from land use change and forestry by 2021. Peru joined the UN-REDD+ Program and the REDD+ Partnership in 2011. In 2014, Peru hosted a meeting of 14 tropical forest nations which issued the so-called "Lima Challenge" in which they committed to take unilateral action to preserve tropical forests but simultaneously challenged wealthy countries to provide funding with which they could reduce deforestation even faster. The same year, Peru signed a Joint Declaration of Intent with Norway and Germany that committed up to $\$ 546$ million in payments for reducing emissions from deforestation.

Indigenous groups initially reacted to the government's interest in REDD + by opposing any engagement with the program. They feared the loss of rights to access and use their lands. Nevertheless, AIDESEP eventually chose to participate in national deliberations and ultimately proposed an alternative formulation that addressed indigenous concerns: the Amazonian Indigenous REDD+ (AIR). AIR recasts REDD+ strategies within a set of concepts and criteria that AIDESEP views as more compatible with the Amazonian indigenous peoples' world views. By participating in the government's REDD + consultation process, AIDESEP has been able, for example, to raise the profile of communal land titling activities in the national strategy and to obtain funding from the World Bank's Dedicated Grant Mechanism (DGM) under which 18 indigenous groups will execute programs. In terms of national policy, the government incorporated AIDESEP's alterative strategy, AIR, when it adopted the National Strategy of Forests and Climate Change (ENBCC).

The indigenous peoples of the Peruvian Amazon are still under threat from violence 25 and economic expansion but the process of implementing international forest conservation agreements has brought greater visibility and new resources to an already strongly organized movement. For example, in San Martín, AIDESEP's local federation is a member of the technical working group on forest zoning as a result of international pressure under the Norway-Germany agreement to ensure that the local government complies with the new

\footnotetext{
${ }^{25}$ http://www.theguardian.com/world/2014/sep/09/illegal-loggers-blamed-for-of-peru-forest-campaigner
} 
forestry law. Substantial effort is now underway to title and register lands under such programs as The Rural Land Titling \& Registration Project in Peru (PTRT-3), Cuatro Cuencas project in Loreto, Forest Investment Program (FIP-Peru), and the Joint Declaration of Intent between the Governments of Peru, Norway and Germany (Lozano 2018). If successful, such land titling programs could significantly reduce deforestation (Blackman et al. 2017). Finally, some resources are flowing directly to communities under the Programa Nacional de Conservación de Bosques (PNCB) which has a program to pay indigenous communities US $\$ 3 /$ ha. to implement forest-based sustainable economic activities and monitor the forest, reaching 120 communities in nine regions. ${ }^{26}$

So far, the implementation of REDD+ in Peru has failed to slow the pace of deforestation or improve the wellbeing of indigenous communities, but it has provided political resources useful to promoting indigenous rights. Peru's commitment to control forest loss is questionable given the increasing rate of deforestation, inconsistencies in the government's forest policies, and weak enforcement of laws meant to constrain commercial pressures on tropical forests and indigenous lands. On the other hand, diverse political pressures led by the indigenous peoples' movements themselves have made some progress on indigenous peoples' rights. Peru's involvement with international REDD + negotiations and agreements have played a key role in shaping new forestry policies and laws; enhancing inter-sectoral coordination; and fostering legitimacy and engagement. This agreement has also affected the land tenure agenda by setting targets, improving procedures, and providing more funding to build capacity and undertake titling and land-use planning processes.

\section{Democratic Republic of the Congo}

The Democratic Republic of the Congo (DRC) has the second largest tropical forest area in the world. Though deforestation has historically been low, its rate has increased in the last two decades, drawing international attention. At the same time, the DRC is among the world's poorest countries and has suffered a series of conflicts that began in the 1990s. It still faces political instability, making it difficult to establish good governance over its entire territory and to carry out the functions necessary for proper management of the country's forests as well as to protect the rights of its peoples.

The DRC has received international support for readiness and implementation under REDD + from UN-REDD, the Forest Carbon Partnership Facility (FCPF), the Central African Forest Initiative (CAFI) and the Forest Investment Program (FIP). It created a special government office, CN-REDD, in 2009 to manage REDD+ activities at the national level and coordinate subnational and private initiatives. It recently launched its national UNREDD program to begin implementation and to test pilot projects. In particular, the DRC's Mai-Ndombe Emissions-Reduction program aims to demonstrate a model of green development that could eventually receive results-based payments for averting greenhouse gas emissions. As in Guyana, the core of the plan is to provide an alternative development

\footnotetext{
${ }^{26}$ http://www.bosques.gob.pe/notasdeprensa/programa-bosques-y-comunidades-nativas-identifican-areas-de-
} bosques-comunales-para-su-conservacion 
strategy for economic activity that does not rely on deforestation, is environmentally sustainable, and simultaneously brings income and benefits to the population.

The war in DRC, continuing violence, and internal displacement have created a special challenge for reducing deforestation, making it difficult for the government to establish the basic conditions for mapping, monitoring, and recognizing land tenure. While international support through REDD+ initiatives often explicitly address governance issues, the efforts are limited due to weak capacity in local jurisdictions, the national government's inability to establish order, and a lack of direct engagement with peace-building initiatives (Brown, H.C.P. 2017).

The Réseau des Populations Autochtones et Locales pour la Gestion durables des Ecosystèmes Forestiers en République Démocratique du Congo (REPALEF/RDC) is a network of indigenous peoples that has been active since 2010 in negotiating and implementing REDD+ projects. It also coauthored an alternative report to the UN Human Rights Committee in which it detailed the lack of a legal framework for recognizing indigenous rights, documented the displacement of indigenous peoples since the colonial period through creation of national parks, and explicitly mentioned the risks that REDD+ initiatives could lead to further violation of indigenous rights. They specifically mentioned that in its implementation of REDD + , the DRC government "should guarantee indigenous Pygmy peoples their rights of access and control over their lands and natural resources." (NGO Report on Indigenous Pygmy Peoples 2013). Furthermore, the government has introduced a new law on the rights of indigenous peoples because of mobilization by organizations like REPALEF/RDC and international pressures through REDD+ (Johns 2015). REPALEF's response in March to a critical report by the Rights and Resources Initiative shows that this organization views REDD+ as more of a resource for indigenous peoples in the DRC than a risk (RRI 2018; REPALEF 2018).

\section{A range of experience but no counterfactual}

Of these five countries, significant reductions in deforestation have only occurred in Brazil. Since deforestation is generally driven by agriculture, mining and settlement expansions, this suggests that the failure of REDD+ to significantly slow deforestation is one of the primary ways in which it is hurting indigenous peoples. In other words, it is the failure to implement REDD+ rather than its implementation that may represent the biggest threat to indigenous peoples in terms of land tenure and social well-being.

Poor implementation of REDD+ initiatives can also hurt indigenous peoples if the resources being applied and the legitimacy conferred by international support are used by powerful domestic political actors to grab resources and displace peoples. Many of the local project evaluations highlight these problems while noting that fuller adherence to FPIC, assuring clarity over land tenure as a precondition for programs, and addressing major drivers of deforestation could avoid them.

In all of these countries, to different degrees, the national level REDD+ initiatives have opened political space for indigenous peoples in ways that have strengthened legal recognition, land tenure and participation, though the direct effects on social well-being are 
less clear. In Brazil, indigenous groups and local communities have been mobilizing for decades to protect their rights. Their engagement with other civil society groups, their affinity with the Workers Party government of President Lula, their support for his Environment Minister, and their eventual collaboration with Brazil's broader environmental movement pushed a model for REDD+ financing which satisfied domestic and international actors alike. The structure of ex post payments recognized what Brazil had already achieved while establishing a benchmark for continued action to control deforestation. While indigenous peoples have achieved many successes, it comes amidst continuing high levels of political and physical conflict. The number of documented killings of environmental activists - most of whom are indigenous-is higher in Brazil than in any other country (Global Witness 2017).

In Guyana, indigenous groups were less organized but have become a pivotal voting bloc in the country's national politics and benefitted from an extensive consultative process required by the national REDD+ program. In Indonesia, indigenous groups have also mobilized to protect their rights and staged particularly vocal opposition to neglect of those rights in the Bali conference on climate change. As part of Indonesia's engagement with Norway, the government has expanded consultation with indigenous groups like AMAN, the Supreme Court has recognized indigenous rights in a landmark case, and special representation has been arranged in many instances. In Peru, Amazonian indigenous peoples' organization is relatively new and yet their mobilization has led to an alternative framing of REDD+ which has been incorporated in the government's national REDD+ strategy. The DRC is the one country where REDD+ has had the smallest impact on indigenous rights, due in part to weaker indigenous organization and mobilization and a government which is politically fragmented and weak.

This comparative analysis lacks a key counterfactual: how would REDD+ have affected deforestation and indigenous peoples' rights if safeguards and conditions had not been introduced into the programs? Except for Brazil, all the other national programs established preconditions for performance payments related to approving strategies, creating government agencies, engaging in consultations, and assuring that policies and projects receive free prior informed consent by affected communities. In Brazil's case, we know that the national commitment to reducing deforestation came prior to the Amazon Fund agreement with Norway as a consequence of the interaction of domestic political dynamics with international pressures. In the other cases, preconditions have been fulfilled imperfectly, generating disillusionment with and suspicion of REDD+ initiatives even when international pressure for engaging in consultations and respecting rights opened political space and generated political resources for use by mobilized indigenous organizations.

Furthermore, the other essential problem remains: the rates of deforestation in all four other countries have continued to rise. It is impossible to know whether a purer performance payment approach in Guyana, Indonesia, Peru or DRC would have led governments to focus attention on the main drivers of deforestation (primarily commercial activities and migratory settlement rather than indigenous slash-and-burn practices) or would have been ignored. In the former case, establishing preconditions for performance payments might have come at the expense of millions of hectares of forest which might otherwise have been 
preserved. In the latter case, the preconditions were worthwhile because the performance payments would not have significantly reduced deforestation and, at least, indigenous peoples achieved gains in terms of political participation and legitimacy. In other words, the international community has found ways to promote indigenous peoples rights; it has not found a way to sufficiently strengthen domestic constituencies who favor preserving forests as a counterbalance to domestic interests favorable to exploiting, deforesting and degrading them.

\section{Conclusions}

As originally envisioned, REDD+ sought to make forests more valuable standing than cut down. However, in practice, REDD+ has become a shorthand for many different kinds of programs - some involving direct action at the community level, others addressing government action at the national or subnational levels. The funds in these programs are spent variously on "inputs" (such as mapping, training, institutional development, studies, and designing regulations); "outputs" (such as numbers of hectares that are legally protected or numbers of enforcement actions); and to a more limited extent "outcomes" (that is, reduced emissions from tropical deforestation and degradation). The implications for reducing deforestation, for indigenous rights, and for compatibility between the two, depend crucially on the character of the program in terms of who pays for what to whom.

It is not surprising that such a range of programs could potentially harm, bypass, or benefit indigenous peoples. First, they could harm indigenous peoples if they create incentives for non-indigenous groups to displace them from their lands in order to gain access to payments or by creating incentives for indigenous peoples themselves to alienate their lands, to alter community practices, and to change their cultures. Second, these programs could leave indigenous peoples unharmed but still leave them without any benefits if the forests are preserved without displacement while financial flows accrue to non-indigenous peoples. Finally, REDD+ programs could benefit indigenous peoples by preserving their forests, by creating financial flows to compensate them for conserving their forests, by giving them greater political recognition as stewards for conservation, and by creating domestic political leverage through international recognition and support.

Fortunately, REDD+ efforts to slow tropical deforestation through national performance payment programs are likely to be compatible with realizing indigenous rights for at least three reasons:

- Where Indigenous Peoples' rights are respected, forests are more likely to be preserved. A preponderance of research has found that the presence of indigenous peoples is associated with less deforestation. While this is not a necessary relationship, traditional indigenous use of tropical forest is less damaging to the environment than typical modern uses like large-scale agriculture, urban settlement or mining. In addition, numerous programs have demonstrated how indigenous peoples' 
knowledge and participation in monitoring and conservation can be effective in preserving tropical forests. ${ }^{27}$

- International payments to reduce deforestation represent the newest most promising strategy for reducing deforestation. This statement remains a hypothesis until such time as substantial funds are put into play. However, Brazil's successful reduction in deforestation between 2004 and 2012 demonstrates that the needed scale of forest conservation requires forceful policies at the national level. Barring the emergence of stronger domestic political movements to counter economic interests that want to profit from deforestation, international payments within the framework of REDD+ are one of the few counterbalances available.

- Threats to Indigenous Peoples are longstanding and REDD+ programs are not the most significant of these threats. The main pressures behind the repression and displacement of indigenous peoples come from individuals and groups who wish to profit from clearing tropical forests to use the lands for other purposes-primarily agriculture, mining, and human settlement. While early proposals to commodify the carbon stocks in tropical forests looked similar to other natural resource booms, there are significant differences. First, paying for carbon stocks requires preserving forests not cutting them down. Second, preserving forests is compatible with continued habitation, tenure security, and use by indigenous peoples in most cases. Third, to the extent that REDD+ programs are successful, they require halting the main drivers of deforestation-like agricultural expansion—which are themselves motivating much of the repression and displacement faced by indigenous peoples.

Thus, the interests of indigenous peoples and international programs to preserve tropical forests are likely to be aligned. Assuring that indigenous rights and preserving tropical forests are complementary rather than competing strategies therefore requires three levels of action. First, care must be taken in designing and implementing local projects, especially when payments for forest conservation can be taken from indigenous peoples or traded. Second, conditions on international agreements that aim to support indigenous rights should be respected and implemented in ways that accelerate progress on slowing deforestation, not in delaying it. Finally, and most importantly, greater emphasis is needed in national level actions that can support domestic constituencies who are willing to confront vested interests and the main drivers of deforestation. The policies and enforcement actions which most directly counter the expansion of commercial agriculture, mining, public infrastructure, and migratory settlement into the world's remaining tropical forests are also those which are likely to be most compatible with securing indigenous rights to customary use of their lands. This is the fundamental challenge that future REDD+ national programs must address.

${ }^{27}$ For a recent empirical test of this hypothesis, see Blackman et al. 2017, showing less forest clearing in Peruvian communities that received land titles between 2002 and 2005. 


\section{References}

Abranches, Sérgio. 2013. "The Political Economy of Deforestation in Brazil and Paymentfor-Performance Finance.” CGD Climate and Forest Paper Series \#10. Washington, DC: Center for Global Development.

Andersson, K.P., Smith, S.M., Alston, L.J., Duchelle, A.E., Mwangi, E., Larson, A.M., de Sassi, C., Sills, E.O., Sunderlin, W.D. and Wong, G.Y., 2018. "Wealth and the distribution of benefits from tropical forests: Implications for REDD+." Land Use Policy, 72: 510-522.

Birdsall, Nancy, William Savedoff, and Frances Seymour. 2014. "The Brazil-Norway Agreement with Performance-Based Payments for Forest Conservation: Successes, Challenges, and Lessons." CGD Brief, Washington, DC: Center for Global Development.

Blackman, A., Corral, L., Lima, E.S. and Asner, G.P., 2017. "Titling indigenous communities protects forests in the Peruvian Amazon." Proceedings of the National Academy of Sciences, 114(16):4123-4128.

Brack, Duncan. 2017. "Woody Biomass for Power and Heat: Impacts on the Global Climate." London: The Royal Institute of International Affairs, Chatham House. February.

Brown, H.C.P. 2017. "Implementing REDD+ in a Conflict-Affected Country: A Case Study of the Democratic Republic of Congo.” Environments, 4(3):61. http://dx.doi.org/10.3390/environments4030061

Busch, Jonah and Kalifi Ferretti-Gallon. 2017. "What Drives Deforestation and What Stops It? A Meta-Analysis," Review of Environmental Economics and Policy, 11(1):3-23. January. https://doi.org/10.1093/reep/rew013

Busch, Jonah, Jens Engelmann, and Alice Lépissier. 2016. "Technical Background Note for Why Forests? Why Now? Chapter 5: Cheaper, Cooler, Faster: Reducing Tropical Deforestation for a More Cost-Effective Global Response to Climate Change." CGD Background Paper. Washington, DC: Center for Global Development. http://www.cgdev.org/sites/default/files/why-forests-chapter5background-note.pdf

Chao, Sophie. 2012. "Forest Peoples: Numbers across the world.” Forest Peoples Programme. https://www.forestpeoples.org/sites/fpp/files/publication/2012/05/forest-peoplesnumbers-across-world-final 0.pdf

Chuecas, A. (2009). "El Derecho de los Pueblos Indígenas en el Contexto Histórico del Perú.” Mimeo. Centro Amazónico de Antropología y Aplicación Práctica. Retrieved from

http://www2.congreso.gob.pe/sicr/cendocbib/con4 uibd.nsf/CD62A7B22B15803A0 5257BCD00771534/\$FILE/Derecho de los_pueblos indígenas_y comunidades.pdf

Ding, Helen, Peter Veit, Erin Gray, Katie Reytar, Juan-Carlos Altamirano, Allen Blackman and Benjamin Hodgdon. 2016. "The Economic Case for Securing Indigenous Land Rights in the Amazon.” Washington, DC: The World Resources Institute. October. http://www.wri.org/publication/climate-benefits-tenure-costs 
DRC (Democratic Republic of the Congo). 2012. "Synthèse des études sur les causes de la déforestation et de la dégradation des forêts en République Démocratique du Congo." UN-REDD Programme. August.

Duchelle, A. E., C. de Sassi, P. Jagger, M. Cromberg, A. M. Larson, W. D. Sunderlin, S. S. Atmadja, I. A. P. Resosudarmo, and C. D. Pratama. 2017. "Balancing carrots and sticks in REDD+: implications for social safeguards." Ecology and Society 22(3):2. https://doi.org/10.5751/ES-09334-220302 Version: 3 Submitted: 2017-03-24

Espinoza Llanos, Roberto and Conrad Feather. "The Reality of REDD+ in Peru: Between Theory and Practice: Indigenous Amazonian Peoples' analyses and alternatives.” Forest Peoples Program.

https://www.forestpeoples.org/sites/fpp/files/publication/2011/11/reality-redd-perubetween-theory-and-practice-november-2011.pdf

Fay, Chip and Ho-Ming So Denduangrudee. Forthcoming. "An Uneven Path toward Rights and REDD+ in Indonesia.” CGD Working Paper. Washington, DC: Center for Global Development.

Forstater, M., Nakhooda, S. and Watson, C., 2013. "The effectiveness of climate finance: a review of the Amazon Fund." London: Overseas Development Institute.

Global Witness. 2017. "Defenders of the Earth: Global killings of land and environmental defenders in 2016." London: Global Witness Limited.

Gracey, M. and King, M. 2009. Indigenous health part 1: determinants and disease patterns. The Lancet, 374(9683):65-75.

Hall, Gillette and Ariel Gandolfo. 2016. "Poverty and exclusion among Indigenous Peoples: The global evidence.” World Bank Voices. http://blogs.worldbank.org/voices/povertyand-exclusion-among-indigenous-peoples-global-evidence

Hansen, Katrine Broch, Kathe Jepsen, and Pamela Leiva Jacquelin. 2017. The Indigenous World Report 2017. Copenhagen: The International Work Group for Indigenous Affairs (IWGIA). http://www.landcoalition.org/sites/default/files/documents/resources/0760 the indig enous orld 2017 eb.pdf

Hansen, M. C., P. V. Potapov, R. Moore, M. Hancher, S. A. Turubanova, A. Tyukavina, D. Thau, S. V. Stehman, S. J. Goetz, T. R. Loveland, A. Kommareddy, A. Egorov, L. Chini, C. O. Justice, and J. R. G. Townshend. 2013. "Hansen/UMD/Google/USGS/NASA Tree Cover Loss and Gain Area." University of Maryland, Google, USGS, and NASA. Accessed through Global Forest Watch on Jan. 22, 2018.www.globalforestwatch.org. Jayachandran, Seema, Joost de Laat, Eric Lambin, and Charlotte Stanton. 2017. "Cash for carbon: A randomized trial of payments for ecosystem services to reduce deforestation." Science 357:267-273.

Jodoin, Sébastien. 2017. Forest Preservation in A Changing Climate: Redd+ And Indigenous and Community Rights in Indonesia and Tanzania. Cambridge University Press.

Johns, Tracy. 2015. "The Impacts of International REDD+ Finance: DRC Case Study." Climate and Land Use Alliance. July. http://www.climateandlandusealliance.org/wpcontent/uploads/2015/08/Impacts of International REDD Finance Case Study D $\underline{\text { RC.pdf }}$

Koch, Nicolas, Erasmus zu Ermgassen, Erasmus, Johanna Wehkamp, Francisco Oliveira, and Gregor Schwerhoff. 2018. "Agricultural Productivity and Forest Conservation: 
Evidence from the Brazilian Amazon.” SSRN Working Paper.

https://ssrn.com/abstract $=3031416$

Laing, Tim. 2015. The Impacts of International REDD+ Finance in Guyana. Climate and Land

Use Alliance.

Laing, Tim. 2018. "Guyana's REDD+ Agreement with Norway: Perceptions of and Impacts on Indigenous Communities.” CGD Working Paper 476. Washington, DC: Center for Global Development. https://www.cgdev.org/publication/guyana-reddagreementnorway-perceptions-and-impacts-indigenous-communities

Lancet-Lowitja Institute. 2016. “A Global Snapshot of Indigenous and Tribal Peoples' Health," November. https://www.lowitja.org.au/sites/default/files/docs/Lancet Lowitja rprt 0.pdf

Land Matrix, 2016. "International Land Deals for Agriculture-Fresh insights from the Land Matrix: Analytical Report II," http://www.landmatrix.org/media/filer_public/ab/c8/abc8b563-9d74-4a47-9548cb59e4809b4e/land matrix 2016 analytical report draft ii.pdf

Land Matrix, 2018. Global Observatory database, accessed Apr. 20, 2018, http://www.landmatrix.org/en/

Lozano, Liliana. Forthcoming. "Peru's Participation in REDD+: Perceptions of and Impacts on Indigenous Communities.” CGD Working Paper. Washington, DC: Center for Global Development.

MINAM. 2015a. ANEXO iNDC - Supuestos y Metodologías contempladas como parte de las Contribuciones Nacionales en Mitigación. http://www.minam.gob.pe/indcs/wpcontent/uploads/sites/100/2015/05/Supuestos-y-Metodologías-contempladas-comoparte-de-las-Contribuciones-Nacionales-en-Mitigación-2.pdf Last accessed June 20, 2018.

MINAM. 2015b. Estrategia Nacional sobre Bosques y Cambio Climático. http://www.bosques.gob.pe/archivo/enbcc-ds-007-2016-minam.pdf Last accessed June 20, 2018.

Naughton-Treves, Lisa and Cathy Day, eds. 2012. "Lessons About Land Tenure, Forest Governance and REDD+: Case Studies from Africa, Asia and Latin America." Madison, Wisconsin: UW-Madison Land Tenure Center. January. http://landwise.resourceequity.org/records/2187

NGO Report on Indigenous Pygmy Peoples. Universal Periodic Review of the Democratic Republic of Congo. 2014. "Indigenous Peoples in the DRC: The injustice of multiple forms of discrimination" Submitted by: FDAPYD, LINAPYCO, OSAPY, PIDP SHIRIKA LA BAMBUTI, PREPPYG, REPALEF/RDC, UEFA to the UN Human Rights Committee, September 2013.

Norad. 2016. "Real-time evaluation of the Government of Norway's International Climate and Forest Initiative: Literature Review and Programme Theory." Evaluation Department Report 2/2016. Oslo: Norad.

Norad. 2017. "Norway's International Climate and Forest Initiative: Lessons learned and recommendations Evaluation Synthesis Report." Evaluation Department Report 8/2017. Oslo: Norad. 
Norman, Marigold and Smita Nakhooda. 2014. "The State of REDD+ Finance.” CGD

Working Paper 378. Washington, DC: Center for Global Development.

http://www.cgdev.org/publication/state-redd-finance-working-paper-378

Oxfam, International Land Coalition, Rights and Resources Initiative. 2016. Common Ground. Securing Land Rights and Safeguarding the Earth. Oxford: Oxfam.

https://landrightsnow.contentfiles.net/media/assets/file/GCA REPORT EN FINA L.pdf

Perakis, R. and Savedoff, W. 2015. "Does results-based aid change anything? Pecuniary interests, attention, accountability and discretion in four case studies." CGD policy paper No. 52. Washington, DC: Center for Global Development.

REPALEF (Réseau des Populations Autochtones et Locales pour la Gestion durables des Ecosystèmes Forestiers en République Démocratique du Congo). 2018. "Réponse de la Société Civil de la République Démocratique du Congo aux Conclusion de L'étude de Rights and Resources Initiative (RRI) Intitulée "Est-ce que le laboratoire REDD va bénéficier aux peuples autochtones et communaues locales? Analyse des impact cumulatifs et risques lies aux initiative REDD.” Kinshasa, DRC. March.

RRI (Rights and Resources Initiative). 2014. "What Future for Reform? Progress and slowdown in forest tenure reform since 2002.” Washington DC: Rights and Resources Initiative. http://rightsandresources.org/wpcontent/uploads/RRI4011D FlagshipMAR2014r13B.pdf

RRI (Rights and Resources Initiative). 2018. "Mai-Ndombe: Will the REDD+ Laboratory Benefit Indigenous Peoples and Local Communities? Analysis of the cumulative impacts and risks of REDD+ initiatives." Washington, DC: Rights and Resources Initiative.

Sarmiento Barletti, Juan Pablo and Anne M. Larson. 2017. "Rights abuse allegations in the context of REDD+ readiness and implementation: A preliminary review and proposal for moving forward." CIFOR Infobrief, No. 190, October. https://doi.org/10.17528/cifor/006630

Sena, Kanyinke. 2009. "REDD and Indigenous Peoples' Rights in Africa." Indigenous Affairs. 1/09. https://www.iwgia.org/images/publications//IA 1-2009 REDD in Africa.pdf.

Seymour, F. and Busch, J., 2016. Why forests? Why now?: The science, economics, and politics of tropical forests and climate change. Washington, DC: Brookings Institution Press.

Seymour, F., Birdsall, N. and Savedoff, W., 2015. “The Indonesia-Norway REDD+ agreement: A glass half-full.” CGD Policy Paper No. 56. Washington, DC: Center for Global Development.

Seymour, Frances and Arild Angelsen. 2012. "Summary and Conclusions, REDD+ Without Regrets.” In A. Angelsen, M. Brockhaus, W.D. Sunderlin, and L.V. Verchot, eds. Analysing REDD+: Challenges and choices. Bogor Barat, Indonesia: Center for International Forestry Research.

Sunderlin, W. D. et al. 2013. "How are REDD+ Proponents Addressing Tenure Problems? Evidence from Brazil, Cameroon, Tanzania, Indonesia, and Vietnam," World Development, 55:37-52. http://dx.doi.org/10.1016/j.worlddev.2013.01.013

Weisse, Mikaela and Liz Goldman. 2017. "Global Tree Cover Loss Rose 51 Percent in 2016.” Global Forest Watch. https://blog.globalforestwatch.org/data/global-tree-coverloss-rose-51-percent-in-2016. 
White, Andy and Alejandra Martin. 2002. "Who Owns the World's Forests? Forest Tenure and Public Forests in Transition." Washington, DC: Forest Trends.

Wily, Liz Alden. 2011. "The tragedy of public lands: The fate of the commons under global commercial pressure.” Rome: International Land Coalition. January.

Yashar, D. J. 2005. "Contesting Citizenship in Latin America: The Rise of Indigenous Movements and the Postliberal Challenge." Cambridge: Cambridge University Press. https://doi.org/10.1017/CBO9780511790966 


\section{Appendix 1: Sources for table 3}

Bastida et al. 2017. http://idesam.org.br/publicacao/mapping-REDD-flows.pdf

Ben-Achour, Arbi, Prospere Backiny-Yetna, and Quentin Wodon. 2011. Indigenous Peoples: Democratic Republic of Congo Country Brief No. 6. Accessed online at: http://siteresources.worldbank.org/EXTINDPEOPLE/Resources/4078011271860301656/DR_Congo_brief.pdf

Bureau of Statistics, Guyana. 2016. Compendium 2: Population Composition. Accessed online at file://C:/Users/msnyder/Downloads/Final_2012_Census_Compendium2.pdf

IBGE, Brazil. 2010. Tabela 1.3.1 Characteristics of Population and of Households, Demographic Census 2010. Accessed online at https://biblioteca.ibge.gov.br/visualizacao/periodicos/93/cd_2010_caracteristicas_pop ulacao domicilios.pdf

IWGIA. 2018. Indigenous peoples in Indonesia. Accessed online: https://www.iwgia.org/en/indonesia

Johns, Tracy. 2015. "The Impacts of International REDD+ Finance: DRC Case Study.” Climate and Land Use Alliance. July. http://www.climateandlandusealliance.org/wpcontent/uploads/2015/08/Impacts of International REDD Finance Case Study D $\underline{\text { RC.pdf }}$

Laing, Tim. 2015. The Impacts of International REDD+ Finance in Guyana. Climate and Land Use Alliance.

Lozano, Liliana. Forthcoming. "Peru's Participation in REDD+: Perceptions of and Impacts on Indigenous Communities." CGD Working Paper. Washington, DC: Center for Global Development.

White and Martin 2002. https://theredddesk.org/sites/default/files/resources/pdf/who owns the worlds forests 0 .pdf

Wolosin, Michael, Jessica Breitfeller, and Brian Schaap. 2016. The Geography of REDD+ Finance: Deforestation, Emissions, and the Targeting of Forest Conservation Finance. Forest Trends. Accessed online at http:// foresttrends.org/releases/p/geography redd finance 


\section{Appendix 2: A formal model to investigate compatibility of forest protection and indigenous rights}

For a framework, consider a simplified model with two primary outcomes: indigenous peoples' well-being and forest cover. Consider the well-being of indigenous peoples to be a function of their autonomy, the amount of forest cover, and their access to other physical or financial resources. Forest cover, in turn, is a function of indigenous peoples' autonomy, prices of commodities that can be produced or extracted through tropical deforestation, land use policies, and law enforcement.

$$
\begin{gathered}
\mathrm{U}_{\mathrm{IP}}=\mathrm{f}(\mathrm{IPR}, \mathrm{F}, \mathrm{PxE}, \mathrm{X}) \\
\mathrm{F}=\mathrm{f}(\mathrm{IPR}, \varrho, \text { PxE })
\end{gathered}
$$

Where IPR is indigenous people's rights; F is forest cover; PxE is the interaction of public land use policies and enforcement; $\mathrm{X}$ is other resources accessed by indigenous peoples; $\varrho$ is a vector of prices for commodities that can be obtained or extracted through deforestation. Using this model, we can formally present the assumptions underlying the alignments or contradictions between rights and forest cover.

\section{Case 1: Forest protection payments to indigenous peoples.}

Paying indigenous peoples for the environmental services provided by their forests increases their resources $(\mathrm{X})$. But their well-being can be either improved or worsened by these payments. On the positive side, indigenous communities who receive funding for preserving their forests will be able to increase their consumption possibilities with respect to goods and services in the wider national economy while continuing to live in or have access to their traditional homes $\left(\mathrm{U}_{\mathrm{X}}>0\right)$. On the negative side, such payments might disrupt indigenous communities by redistributing power and resources within communities or by changing their relationship with the forest from traditional norms to economic commodities $\left(\mathrm{U}_{\mathrm{X}}<0\right)$.

\section{Case 2: The relationship between indigenous peoples' rights and forest cover}

Indigenous peoples rights affect their own well-being and the amount of forest cover. Indigenous rights are almost certainly beneficial to indigenous peoples, so there is no question about that relationship (i.e. $\mathrm{U}_{\mathrm{IPR}}>0$ ). However, the impact of indigenous peoples' rights on forest cover have been contested and for years it was argued that they were primarily responsible for deforestation through rotational agriculture and other traditional practices. More recent literature shows that indigenous peoples are not a significant cause of deforestation and that the more that they have secure land tenure and their rights are respected, the more likely that forest cover is maintained ( $\left.F_{I P R}>0\right)$. Nevertheless, it is possible for secure land tenure by indigenous peoples to turn into higher rates of deforestation if they were to choose to exploit their lands $\left(\mathrm{F}_{\mathrm{IPR}}<0\right)$; in such an event, the role of land use policy could play a mitigating role but protecting indigenous rights and preserving forest cover would be competing not complementary strategies.

Case 3: Land use policies and enforcement.

Land use policies and enforcement will affect indigenous peoples' well-being as well as forest cover. Some land use policies will improve both $\left(F_{P}>0 ; U_{P}>0\right)$ as, for example, when 
indigenous peoples enjoy secure land tenure and government enforces their rights to traditional land use. Some land use policies, however, may generate tradeoffs. For example, prohibiting rotational agriculture in a national park will protect forests but may harm indigenous peoples $\left(\mathrm{F}_{\mathrm{P}}>0 ; \mathrm{U}_{\mathrm{P}}<0\right)$. In some cases, the effects of a given land use policy is ambiguous or depends critically on how indigenous peoples themselves view the benefits of development. For example, road construction increases the likelihood of deforestation but also provides indigenous peoples with access to social services and cheaper products from the rest of the economy. The impact of road construction on forest cover is clear $\left(\mathrm{F}_{\mathrm{p}}<0\right)$, but whether this will improve or harm indigenous peoples' well-being will depend on their perspectives (i.e. is $\mathrm{U}_{\mathrm{P}}>0$ or $\mathrm{U}_{\mathrm{P}}<0$ ). 


\section{Appendix 3: Search process for prospective criticism of REDD+}

We conducted a detailed search of articles which discussed REDD + in terms of its potential impact on indigenous peoples, published from 2006 to 2011. The search was conducted in three phases, the first of which focused on prospective criticism of REDD between 2006 and 2011 using a range of search terms. The second phase sought to identify empirical studies of the impact of REDD+ on indigenous peoples over the same time frame. A final search phase narrowed the list of articles to those addressing 13 specific issues related to indigenous peoples and REDD+ implementation. The result was a database of 43 articles, most of which were clustered in 2008 and 2009.

This review was conducted in three stages, and the reports and articles covered in the review were identified through a combination of Internet queries and sources. The review methodology generated publications from academic and grey literature, non-scholarly materials, such as blogs and newspaper articles, and advocacy materials. A limited number of non-scholarly and advocacy materials were selected for review in the first and second stages of the literature search and were excluded from the third stage, although reports in the grey literature from non-profit organizations engaged in advocacy for indigenous rights under REDD and REDD+ were considered. De-personalization tools were not used for any Internet queries.

The first stage of the review encompassed literature searches conducted on REDD, REDD + and early criticisms of those programs. This stage was conducted between October-December 2016. Initially, the first stage search was limited to literature that was published in the four years from 2006-2009, primarily capturing publications after the UNFCCC formally called for REDD demonstration activities in 2007. The search was then expanded to encompass six years, through 2011. Under these time of publication constraints, a query was run in Google Scholar using the phrases "REDD criticisms," "REDD+ criticisms," "Indigenous Rights and REDD" and "Property Rights and REDD." The same query phrases were run through the Georgetown University Library electronic database. A subset of relevant literature was selected for further review. This subset of 43 articles and reports was selected on 12 issue categories of early criticism deemed relevant: 1) Property Rights; 2) MRV Problems; 3) Benefit Streams; 4) Non-State Actors; 5)

Institutions/Corruption/Governance; 6) Indigenous Rights; 7) Problematic Satellite Data; 8) Land Use; 9) Determining Appropriate Baselines; 10) Leakage; 10) Transparency/Accountability; 11) Perverse Incentives; and 12) Permanence.

The second stage of the review encompassed literature searches on the evidence base of REDD and REDD+ implementation efforts and observed beneficial or harmful effects of REDD and REDD+ on indigenous peoples. This stage was conducted between April-June 2017. Queries were run in Google Scholar using the Boolean search terms "REDD" AND "implementation" AND "indigenous people"; "REDD” AND "evaluation” AND "indigenous people"; "REDD” AND "evidence" AND "indigenous people." The same terms were run through the George Washington University Library electronic database. A 
subset of relevant literature was selected for further review. This subset of 37 articles and reports was selected based on relevance to the beneficial or harmful effects of REDD and REDD+ on indigenous peoples specifically, although literature assessing the effects of REDD and REDD+ on forest-dependent peoples and local forest communities was also considered. In selecting literature for review, priority was given to articles and reports that offered empirical evidence of the effects of REDD on indigenous peoples (most frequently, evidence was limited to a single country or case, or limited to REDD demonstration activities). However, due to the low levels of published empirical assessments of REDD implementation in the REDD literature, papers and reports predicting prospective effects were also included in the review.

The third stage of the literature review was conducted between September-October 2017. A Google Scholar query and a Google query were conducted using the Boolean search terms "risks opportunities" AND "indigenous people” AND "REDD.” A Google Scholar query and a Google query were also conducted without Boolean operators on the phrase "risks opportunities indigenous people REDD." The same terms were run through the George Washington University Library electronic database. Additionally, bibliographies of articles selected for inclusion in the review suggested additional literature to be investigated. Beyond the Internet queries conducted in the third stage of the literature review, a further subset from the literature identified in the first and second stages was selected as relevant to the risks and opportunities posed to indigenous peoples by REDD and was included in the third stage review.

From the prospective studies included in the second stage of the review, a cascading list of comprehensive and non-overlapping mechanisms was generated on the ways REDD could influence indigenous peoples. A second list was created of risks and opportunities posed to indigenous peoples by REDD through these mechanisms. This list of risks and opportunities formed the criteria for inclusion in the third and final stage of the literature review. Articles and reports were required to cover at least one of 13 potential mechanisms through which REDD could pose a risk or an opportunity to indigenous peoples. All 42 papers ultimately selected for review covered multiple criteria. No literature was encountered in the third stage of the literature search that did adequately discuss the risks and opportunities posed to indigenous peoples by REDD but did not meet any of the criteria. Based on the declining level of articles and reports being included in the review by the end stages of the literature search, due to lack of relevancy and literature already having been captured by previous queries, there is a high level of confidence that relevant literature is comprehensively included in this review. While the literature on the predicted risks and opportunities of REDD is extensive, most papers were excluded for one of several reasons: 1) Peripherally referencing REDD while primarily investigating other forestry or environmental policies in relation to indigenous peoples; 2) Referencing specific topics within REDD such as assessment of carbon stocks by indigenous peoples that did not relate to the designated scope of this review; 3) Investigating contextual issues such as perceptions of equity, but not addressing the risks and opportunities posed by those contextual issues to indigenous peoples; 4) Systematically but broadly reviewing research methods or representations of certain topics in the REDD literature; 5) Investigating general 
relationships between actors or power structures; and 6) Describing the risks and opportunities of REDD broadly in relation to non-private and non-governmental entities, but inability to reasonably apply findings to indigenous peoples. The most common reason for excluding literature from the review was a report or article's lack of direct reference or applicability to indigenous peoples. 


\section{Appendix 4: 43 articles with prospective analysis of the impact of REDD+ on indigenous peoples}

Anderson, Nicholas. "REDDy or not? The Effects on Indigenous Peoples in Brazil of a Global Mechanism for Reducing Emissions from Deforestation and Degradation." http://www.ccsenet.org/journal/index.php/jsd/article/view/4238/3680.

Bayrak, Mucahid Mustafa and Lawal Mohammed Marafa. "Ten Years of REDD+: A Critical Review of the Impact of REDD+ on Forest-Dependent Communities." doi: $10.3390 /$ su 8070620 .

Chhatre, Ashwini et al. "Social safeguards and co-benefits in REDD+: a review of the adjacent possible.” http://dx.doi.org/10.1016/j.cosust.2012.08.006.

Cotula, Lorenzo and James Mayers. "Tenure in REDD: Start-point or afterthought?” http://pubs.iied.org/pdfs/13554IIED.pdf

Crippa, Leonardo and Gretchen Gordon. "International Law Principles for REDD+: The Rights of Indigenous Peoples and the Obligations of REDD+ Actors."

http://staging.ilrc.vm-host.net/sites/default/files/201309\%20REDD $\% 20$ Principles $\% 20$ ENG $\% 20$ FINAL $\% 20$ Ref.pdf.

Davis, Crystal et al. "A Review of 25 Readiness Plan Idea Notes from the World Bank Forest Carbon Partnership Facility." http://www.wri.org/sites/default/files/pdf/world bank readiness review.pdf.

Dooley, Kate, Iola Leal, and Saskia Ozinga. "An Overview of Selected REDD Proposals." http://www.fern.org/sites/fern.org/files/media/documents/document 4314 4315.pdf

Dressler, Wolfram et al. "REDD Policy Impacts on Indigenous Property Rights Regimes on Palawan Island, the Philippines.” https://link.springer.com/article/10.1007/s10745-012$\underline{9527-y}$

Erni et al. "Briefing Paper on REDD+, Rights and Indigenous Peoples: Lessons from REDD+ Initiatives in Asia."

http://ccmin.aippnet.org/attachments/article/1068/Doha\%20briefing\%20Final\%20Artwor k.pdf.

Espinoza Llanos, Roberto and Conrad Feather. "The Reality of REDD+ in Peru: Between Theory and Practice." https://www.forestpeoples.org/sites/fpp/files/publication/2011/11/reality-redd-perubetween-theory-and-practice-november-2011.pdf.

Freudenberger, Mark and David Miller. "Climate Change, Property Rights, and Resource Governance: Emerging Implications for USG Policies and Programming." https://www.climatelinks.org/sites/default/files/asset/document/USAID Land Tenure Climate Change and Tenure Issue Brief-061214.pdf.

Freudenthal, Emmanuel, Samuel Nnah, and Justin Kenrick. "REDD and Rights in Cameroon." http://www.forestpeoples.org/en/topics/forest-carbon-partnership-facilityfcpf/publication/2011/redd-and-rights-cameroon-review-trea. 
Ghazoul et al. "REDD: A Reckoning of Environment and Development Implications." http://www.sciencedirect.com/science/article/pii/S0169534710000649

Griffiths, Tom. “Seeing ‘REDD’?: Forests, Climate Change Mitigation and the Rights of Indigenous Peoples and Local Communities."

http://www.forestpeoples.org/sites/fpp/files/publication/2010/08/seeingreddupdatedraft $\underline{3 \text { dec08eng.pdf }}$

Hall, Ronnie. "REDD: The Realities in Black and White." http://www.foei.org/wpcontent/uploads/2014/01/REDD-ingles-final-17-11.pdf.

Huettner, Michael. "Risks and opportunities of REDD+ implementation for environmental integrity and socio-economic compatibility."

http://www.sciencedirect.com/science/article/pii/S1462901111001523.

Larson, Anne. "Forest Tenure Reform in the Age of Climate Change: Lessons for REDD+.” http://www.sciencedirect.com/science/article/pii/S0959378010001111.

Lawlor et al. "Community Participation and Benefits in REDD+: A Review of Initial

Outcomes and Lessons.” http://www.mdpi.com/1999-4907/4/2/296.

Lawlor, Kathleen and David Huberman. "Reduced emissions from deforestation and forest degradation (REDD) and human rights."

http://www.cifor.org/publications/pdf files/Books/BSunderland0901.pdf.

Lemaitre, Sophie. "Indigenous Peoples' Land Rights and REDD: A Case Study."

http://onlinelibrary.wiley.com/doi/10.1111/j.1467-9388.2011.00716.x/full.

Moss, Nicholas et al. "A Review of Three REDD+ Safeguard Initiatives."

https://www.cbd.int/forest/doc/analysis-redd-plus-safeguard-initiatives-2011-en.pdf.

Naughton-Treves, Lisa and Cathy Day. "Lessons About Land tenure, Forest Governance and REDD+: Case Studies from Africa, Asia and Latin America."

http://landwise.resourceequity.org/records/2187

Osborne, Tracey, Laurel Bellante, and Nicolena von Hedemann. "Indigenous Peoples and

REDD+: A Critical Perspective.” http://ppel.webhost.uits.arizona.edu/ppelwp/wp-

content/uploads/2014/11/Osborne IPCCA FINALREDDreport.pdf

Pelletier, Johanne, Nancy Gélinas and Margaret Skutsch. "The Place of Community Forest Management in the REDD+ Landscape." http://www.mdpi.com/1999-

$\underline{4907 / 7 / 8 / 170 / \mathrm{html}}$.

Pierce Colfer, Carol. “Marginalized Forest Peoples' Perceptions of the Legitimacy of

Governance: An Exploration."

http://www.sciencedirect.com/science/article/pii/S0305750X11000829.

Poffenberger, Mark and Kathryn Smith-Hanssen. "Forest Communities and REDD Climate Initiatives."

http://www.eastwestcenter.org/system/tdf/private/api091.pdf?file $=1 \&$ type=node\&id $=323$ $\underline{66}$ 
Poudel, Mohan et al. "Social Equity and Livelihood Implications of REDD+ in Rural Communities- A Case Study from Nepal."

https://www.thecommonsjournal.org/articles/10.18352/ijc.444/.

Raftopoulos, Malayna. "REDD+ and Human Rights: Addressing the Urgent Need for a Full Community-Based Human Rights Impact Assessment."

http://www.tandfonline.com/doi/abs/10.1080/13642987.2015.1115266?journalCode=fjhr2 $\underline{0}$.

Reed, Pablo. "REDD+ and the Indigenous Question: A Case Study from Ecuador." http://www.mdpi.com/1999-4907/2/2/525.

Saeed, Abdul-Razak, Constance McDermott, and Emily Boyd. "Are REDD+ Community Forest Projects Following the Principles for Collective Action, As Proposed By Ostrom?" https://www.thecommonsjournal.org/articles/10.18352/ijc.700/.

Schroeder, Heike. "Agency in international climate negotiations: the case of indigenous peoples and avoided deforestation." https://link.springer.com/article/10.1007/s10784-0109138-2.

Sena, Kanyinke, Myrna Cunningham and Bertie Xavier. "Indigenous People's Rights and Safeguards in Projects Related to Reducing Emissions from Deforestation and Forest Degradation: Note by the Secretariat." http://repository.un.org/bitstream/handle/11176/301230/E C.19 $2013 \quad 7$ EN.pdf?sequence $=3$ \&isAllowed $=\mathrm{y}$. repository.un.org $/$ handle $/ 11176 / 301230$

Sena, Kanyinke. "REDD and Indigenous Peoples' Rights in Africa." https://www.iwgia.org/images/publications//IA 1-2009 REDD in Africa.pdf.

Shankland, Alex and Leonardo Hasenclever. "Indigenous Peoples and the Regulation of REDD+ in Brazil: Beyond the War of the Worlds?"

http://iieb.org.br/files/5813/5299/4629/artigo indigenous people Brazil Leonardo Hase nclever Alex Shankland.pdf.

Sommerville, Matthew. "Land Tenure and REDD: Risks to Property Rights and Opportunities for Economic Growth." http://www.usaidltpr.com/sites/default/files/USAID_Land_Tenure_Land_Tenure and_R EDD_Issue Brief 0. pdf.

Springer, Jenny and Peter Bille Larsen. "Community Tenure and REDD+." https://c402277.ssl.cf1.rackcdn.com/publications/460/files/original/Report - Tenurfinal.pdf?1348687292

Sunderlin, William et al. "How are REDD+ Proponents Addressing Tenure Problems? Evidence from Brazil, Cameroon, Tanzania, Indonesia, and Vietnam." http://dx.doi.org/10.1016/i.worlddev.2013.01.013

Thompson, Mary, Manali Baruah, and Edward Carr. "Seeing REDD+ as a Project of Environmental Governance." http://www.sciencedirect.com/science/article/pii/S1462901110001619. 
Van Dam, Chris. "Indigenous Territories and REDD in Latin America: Opportunity or Threat?" http://www.mdpi.com/1999-4907/2/1/394.

White, Douglas. "A perfect storm? Indigenous rights within a national REDD+ readiness process in Peru https://link.springer.com/article/10.1007/s11027-013-9523-6

Wright, Glen. "Indigenous People and Customary Land Ownership Under Domestic REDD+ Frameworks: A Case Study of Indonesia." http://www.leadjournal.org/content/11117.pdf.

WWF Forest and Climate Initiative and Rights and Livelihoods Program. "Free, Prior, Informed Consent and REDD+: Guidelines and Resources."

https://www.worldwildlife.org/publications/free-prior-informed-consent-and-reddguidelines-and-resources. 